\title{
Survival Factors of Seventeenth-Century Hand- Press Books Published in the Southern Netherlands: The Importance of Sheet Counts, Sammelbände and the Role of Institutional Collections
}

\section{Goran Proot}

In this chapter I deal with products of the printing press in the Southern Netherlands in the seventeenth century and specifically that part of it that is known to us through the Short Title Catalogue Flanders (STCV), the bibliography of early modern hand-press books produced or published in this region. In addition to an analysis of what has thus far been recorded in this retrospective bibliography, I will develop a quantitative approach to that part of book production which has not yet been entered in the sTCV. The aim of this discussion is to obtain a better understanding of the role of institutional collections and the characteristics of their holdings, of the coverage ratio of the STCV, and of the factors which have a significant impact on survival rates of Early Modern books. This will help establish more clearly what, on the one hand, we can know about the recorded book production - directly, through the works actually described in bibliographies, and, indirectly, what may be added to them in the future - and what, on the other hand, escapes from our knowledge: for much of what has been published has never been collected by institutions, or has not survived in sufficiently large quantities, preventing any scientific estimate of the relationship between known and lost fractions of documents. On the following pages I will not speculate on the latter category of 'dark matter', which is fundamentally unknowable, but concentrate on the book production directly and indirectly known through the STCV and on the limits of this tool. ${ }^{1}$

First of all, I will briefly discuss the method that figures at the heart for this survey and the conditions under which it can be used. This will be followed by a sketch of the aims, scope, and actual content of the Short Title Catalogue Flanders, and the corpus I derived from it for my analysis. In the following sections I will discuss the results of this survey and how the outcomes can help

1 For a discussion of 'dark matter' or 'black holes' in bibliographic knowledge, see Piet Verkruijsse, 'Waslijstjes en wenslijstjes. Zwarte gaten in de Nederlandse retrospectieve bibliografie', Jaarboek voor Nederlandse boekgeschiedenis, 16 (2009), pp. 45-51. 
assess specific subsets of bibliographical data, such as the known production of individual printers and their profiles. In the concluding remarks, I will come back to the lurking but fundamental theme hinted at in this introduction, i.e., what do we actually know about the output of the printing press, and how this knowledge is inevitably biased by the laboratory, methods, and instruments used in generating that knowledge.

\section{On the Method}

In 2006, together with Leo Egghe, I developed a mathematical model enabling 'the estimation of the number of lost multi-copy documents', first published in the Journal of Informetrics in 2007, and a year later, in the Papers of the Bibliographical Society of America. ${ }^{2}$ The second article was re-edited and contextualised for an audience of book historians. It explains the method step by step in a comprehensible way. Specific to this method is the fact that it includes the notion of 'multi-copy documents' and that it uses the information about the number of items recorded for each document. This dimension is lacking in most studies aiming at an estimate of the total output of printing presses. ${ }^{3}$ Instead of the rather abstract terms of 'multi-copy document' and 'item', the latter article refers to 'editions' and 'copies', which in the end are just other names for the same things. The method was tested on a specific collection of printed ephemera, quarto editions of theatre programmes published by the Jesuits in their Provincia Flandro-Belgica, typically consisting of one or one half sheet of paper.

As explained in the articles cited, the mathematical method can, under specific circumstances, be used to estimate the total production of different editions based on a random sample of individual copies. More precisely, the model is a stochastic model, based on the notion that an individual copy of an

2 Leo Egghe and Goran Proot, "The estimation of the number of lost multi-copy documents: A new type of informetrics theory', Journal of Informetrics, 1 (2007), pp. 257-268; Goran Proot and Leo Egghe, 'Estimating editions on the basis of survivals: printed programmes of Jesuit plays in the Provincia Flandro-Belgica before 1773, with a note on the "Book Historical Law"', The Papers of the Bibliographical Society of America, 102 (2008), pp. 149-174.

3 See, for instance, Michael F. Suarez, 'Towards a bibliometric analysis of the surviving record, 1701-180o', in Michael F. Suarez and Michael L. Turner (eds.), The Cambridge History of the Book in Britain, vol. v: 1695-1830 (Cambridge: Cambridge University Press, 2009), pp. 39-65. An exception is Jean-François Gilmont, 'Livre, bibliographie et statistiques', Revue d'histoire ecclésiastique, 65 (1970), pp. 797-816, who takes the number of surviving copies in institutional collections into consideration. 
edition has a chance (or probability) of disappearing. Only when all copies of a specific edition are lost is the edition itself irrevocably lost. This means that an edition produced in a print run of 500 copies, is completely lost only if each one of those 500 individual copies is lost.

If the process of the disappearance of copies is a random process, there is a mathematical relationship between the chances that exactly one copy of a specific edition survives, that exactly two copies of a specific edition survive, or three, or four, and so on. Intuitively, one could compare this with playing dice. There is one chance in six of throwing a six; to throw two sixes in a row also has a specific probability, which can be determined stochastically, and the same goes for three sixes in a row, four sixes in a row, and so on. Each outcome has a specific likelihood, and that chance can be mathematically determined.

Let me use another analogy to explain how mathematics can be used to assess the total number of editions. Imagine a big bag containing 150,00o balls, namely 1,00o groups of 150 balls each in a different colour: 150 green balls, 150 red balls, 150 blue balls and so on. If you draw one ball from the bag without looking, you will have one ball of this colour in your collection. If you repeat that process, in the beginning you will most likely draw balls of different colours, but at a given moment, you will begin to draw more often balls of a colour you already have in your collection. The more balls you draw, the more duplicates you will find. If you stop after 1,0oo balls, the chances are that you will have found a high number of balls of a specific colour that only turn up once in your collection. Those are sometimes called singletons. But a smaller part of it will consist of pairs of balls of a specific colour (duplicates), and some colours will be present three times (triplets), some even four times (quadruplets). A typical distribution of colours will look like table 8.1:

Each time this exercise is repeated, the outcome is more or less the same. The proportions of colours found only once, found twice, found three times

TABLE 8.1 Typical distribution of multi-copy documents when drawn randomly from a large collection.

\begin{tabular}{llcr}
\hline & \multicolumn{2}{c}{ No. of multi-copy documents } & \multicolumn{1}{l}{ Copies } \\
\hline $\mathrm{P}_{1}$ & Colours found 1 time & 400 & 400 balls \\
$\mathrm{P}_{2}$ & Colours found 2 times & 220 & 440 balls \\
$\mathrm{P}_{3}$ & Colours found 3 times & 40 & 120 balls \\
$\mathrm{P}_{4}$ & Colours found 4 times & 10 & 40 balls \\
$\mathrm{N}_{\text {Found }}$ & & 660 & 1, ooo balls \\
\hline
\end{tabular}


and so on, will also be more or less the same, as they abide by the laws of probability. The stochastic model we developed makes it possible to estimate, on the basis of a large enough random sample, the total number of different colours - even if not all different colours show up in the sample - because the findings about the recorded colours contain information about those not recorded.

The first step concerns the estimation of the number of multi-copy documents (in the example: different colours) that did not turn up in the sample, called lost documents. For this we use an equation requiring three elements: (1) the number of the most populated category of different multi-copy documents; in the example (Table 8.1) this is indicated as $\mathrm{P}_{1}: 400$; (2) the number of the second highest populated category $\left(\mathrm{P}_{2}: 220\right)$; and $(3)$, the number of copies of the multi-copy documents, in the example this is 150 (there are 150 balls of each different colour). In the case of editions, this is the print run. In the equation, this number is indicated as $a$.

Entering these numbers into the following equation, gives an estimate of multi-documents of which any copy turned up in the sample. In the equation, this number is indicated as $\mathrm{P}_{0}$ :

$$
\mathrm{P}_{0}=\left(\frac{1}{1+\frac{2 \mathrm{P}_{2}}{(\mathrm{a}-1) \mathrm{P}_{1}}}\right)^{\mathrm{a}}
$$

$\mathrm{P}_{0}$ is a fraction of the total population of multi-documents (in the example this is the total number of different colours), $\mathrm{N}_{\text {total }}$, which was not found in the sample $\left(\mathrm{N}_{\text {lost }}\right)$. With these elements, it is possible to calculate the fraction of the different multi-copy documents found, since $\mathrm{N}_{\text {total }}=\mathrm{N}_{\text {found }}+\mathrm{N}_{\text {lost }}$.

In the example, $\mathrm{P}_{0}=0.3312$. This is the fraction of lost colours $\left(\mathrm{N}_{\text {lost }}\right)$. This makes it possible to determine the fraction of found colours $\left(\mathrm{N}_{\text {found }}\right): 0.6688$. Because it is known from the sample what $\mathrm{N}_{\text {found }}$ stands for, namely 660 , it is now possible to calculate $\mathrm{N}_{\text {lost }}: 660 / 0.6688 \times 0.3312=326.84$ or $\approx 327$. The outcome for the total population is $660+327=987$, which is pretty close to the real total population.

The outcome of this exercise is close, but not exact. Two factors are of importance for the accuracy of the estimation: the size of the total population on the one hand, and the size of the random sample on the other. The smaller the former, and the bigger the latter, the more accurate the outcome will be. Tests show that samples of 1,00o items taken from a corpus of 1,000 different multi-copy documents are quite reliable. This is demonstrated by Fig. 8.1, 


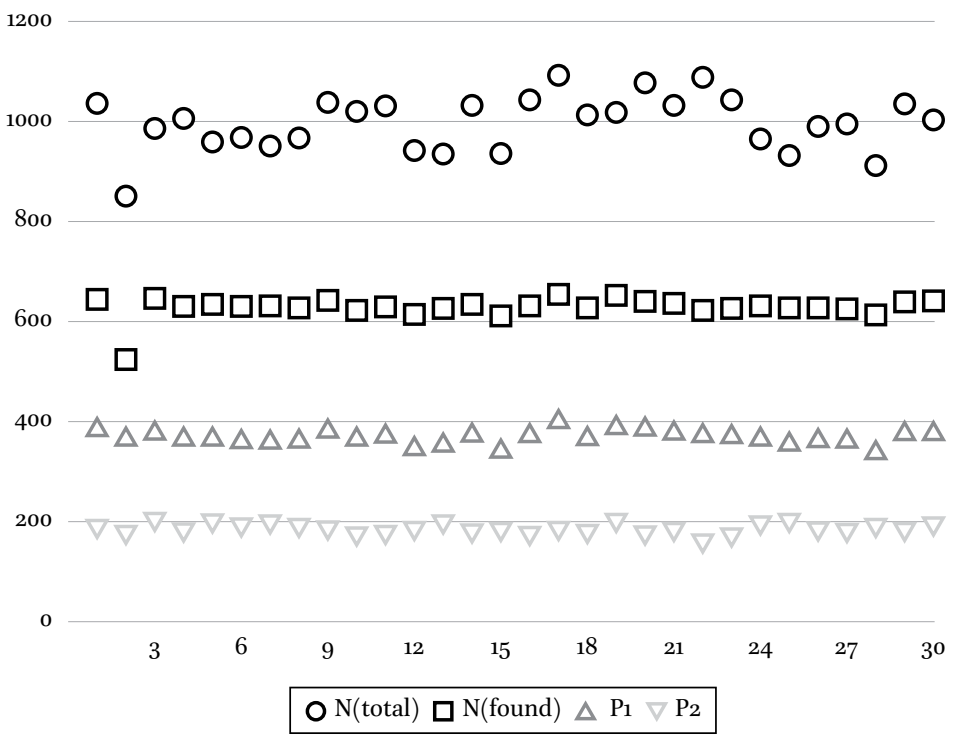

FIGURE 8.1 Results for estimates of $N($ total) based on random samples each of 1 , ooo items. Corpus of 1,0oo multi-copy documents, $a=150$, 30 different samples

featuring the results of 30 random samples, for $\mathrm{P}_{1}, \mathrm{P}_{2}, \mathrm{~N}_{\text {found }}$ and the estimation for $\mathrm{N}_{\text {total }}$ based on the three former values. The average of all 30 estimations for $\mathrm{N}_{\text {total }}$ is $\approx 996$ (996.53). The lowest estimate differs $14.90 \%$ from the actual population (minimum value: 851 ; maximum value: 1,092).

Figure 8.2 shows the results of 30 samples of 20,000 items randomly taken from a corpus of 20,000 multi-copy documents, each of which exists in a run of 150 , in total resulting in a corpus of 3,000,000 items. Although this corpus is 20 times larger than the first test corpus, the estimates are remarkably precise: the average estimate for $\mathrm{N}_{\text {total }}$ is $\approx 20,049(20,049.20$; minimum value: 19,469; maximum value: 20,546 ). This is due to the size of the random sample, which with 20,000 items returns very accurate estimates; the highest estimate differs only $2.73 \%$ from the actual total number of multi-copy documents.

There are a number of conditions attached to the use of this stochastic model to estimate the number of multi-copy documents. First of all, the corpus has to consist of multi-copy documents, that is, a number of series of identical copies, and they have to be distinguished as such. In bibliographies, usually this is the case. The STCV describes editions based on the autopsy of copies of physical books. Editions are identified on the basis of a fingerprint, 
22500

$18750 \stackrel{0000000000000000000000000000}{0}$

15000

ㅁㅁㅁㅁㅁㅁㅁㅁㅁㅁㅁㅁㅁㅁㅁ 11250

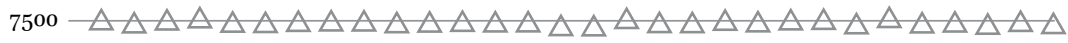

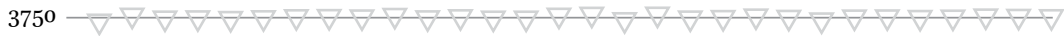

\begin{tabular}{|c|c|c|c|c|c|c|c|c|c|}
\hline \multirow[t]{2}{*}{3} & 6 & 9 & 12 & 15 & 18 & 21 & \multirow[t]{2}{*}{24} & \multirow[t]{2}{*}{27} & \multirow[t]{2}{*}{30} \\
\hline & & & tal) & $\mathrm{V}$ (fou & $\Delta P$ & $\mathrm{P}_{2}$ & & & \\
\hline
\end{tabular}

FIGURE 8.2 Results for estimates of $N($ total $)$ based on random samples each of 20,00o items. Corpus of 20,000 multi-copy documents, $a=150$, 30 different samples

developed and used by the STCN (Short Title Catalogue, Netherlands) project. ${ }^{4}$ The total number of editions is known, as well as the distribution of editions per category (singletons, duplicates, triplets, and so on).

Although the print run (the parameter indicated as $a$ ) cannot be established for the majority of editions, it is safe to state that this number varies between 100 and $3,000 .{ }^{5}$ Using a printing press for print runs much smaller than 100

4 For an overview of the activities of the STCN, see the special issue of the Jaarboek voor Nederlandse boekgeschiedenis, 16 (2009), especially pp. 1-88. The so-called Dutch fingerprint, systematically used by the STCN and the STCV, was introduced by J. Gerritsen, see P.C.A. Vriesema, 'The stcn Fingerprint', Studies in Bibliography, 39 (1986), pp. 93-100, which was also published in Dutch by the same author as 'De STCN-vingerafdruk', Documentaal. Informatie- en communicatiebulletin voor neerlandici, 15 (1986), pp. $55^{-61 .}$

5 For seventeenth-century Paris, Henri-Jean Martin found that print runs fluctuated around the number of 1,350 copies, cf. Gilmont, 'Livre, bibliographie et statistiques', p. 802, footnote 1. I analysed the print runs of 470 editions and (parts of editions on special paper) produced by Plantin's successors between 1601 and 1615 , using $\mathrm{M} 39$, fols. $16 v-24 r$ in the Museum Plantin-Moretus in Antwerp (henceforth: MPM). The mathematical average is about 1,168 copies, the mean is 1,250 copies. $95.96 \%$ of the print runs are larger than $100,86.60 \%$ of the 
was uneconomic and inefficient. More importantly, given that print runs in most cases easily exceed 100 copies, the exact size becomes unimportant for the outcome of the estimations when using our mathematical model. Entering in the formula either 100 or 1,00o for $a$ (the print run), modifies the outcome of the calculations by less than $1 \%$. For the estimates following in the next sections, I will assume that $a$ is 500 , which is the number of sheets in one ream of paper. ${ }^{6}$

\section{Random Sample}

Now that all conditions are fulfilled to use the stochastic method, one question remains to be answered: can a bibliography, such as the STCV, be considered to offer a random sample from the entire population of editions? Stated as such, the answer is definitively no - I will come back to this point in the following pages. But I do believe that the STCV, in its present state, can be considered a random sample of a specific part of the seventeenth-century hand-press book production in the Southern Netherlands, and that it can be used to obtain more information about this part of book production. There are at least three important elements contributing to this status. The first one has to do with the nature of the printed book as an object of perfect distribution, the second one has to do with the rationale of collecting institutions, and the third one with time.

Ideally, all copies of a specific edition are, after a certain time, directly or indirectly, optimally distributed over as many owners as there were copies

print runs are 500 copies and over. The most frequent numbers of print runs are: 1,500 copies ( 58 editions), 1,250 copies ( 36 editions), 1,550 copies ( 36 editions), 1,00o copies ( 31 editions) and 750 copies ( 28 editions).

6 According to Steven van Impe, in the Southern Netherlands a ream of paper counted 480 sheets, but in other regions a ream counted often 500 sheets, cf. Steven van Impe, "Schrijfpapieren van diversche groote en qualitijten" De papierwinkel van P.J. Parys in achttiendeeeuws Antwerpen', Jaarboek voor Nederlandse boekgeschiedenis, 21 (2014), pp. 135-153, here p. 140. Because one ream consisted of 20 quires, one quire of paper counted either 24 or 25 sheets, see also Philip Gaskell, A new introduction to bibliography (2nd edition, New Castle, DE: Oak Knoll Press, 2006), p. 59: '...the smaller ream (480 sheets) being normal in England and Holland, while the larger ream (500 sheets) became standard in most but not all French and Italian mills.' It is not clear whether Van Impe's figures specifically pertain to writing paper only, to paper for printing, or both. All but one print runs for the 470 editions (and parts of editions on special paper) produced by Plantin's successors between 1601 and 1615 are multiples of 25 (cf. MPM M 39). Logically, typographers in this firm calculated with quires of 25 , and with reams of 500 sheets. The exception concerns a 1613 quarto edition of Justus Lipsius's Leges regiae (м 39, f. 23r; STCV 12919412; copy Folger Shakespeare Library, DH811 A63 $\mathrm{S}_{3}$ Cage fo.5). This eight-page publication was printed on a run of 1,111 copies for a total amount of 27 gulden 15.5 stuivers (or 0.5 stuiver per copy). 
printed. It is in the interest of the person who takes the risk by investing in a book project to sell as many copies as quickly as possible in order to recuperate his investment and to make a profit as soon as all production costs are paid off. He can do this by retailing all copies himself, if the book is intended for a local audience; by furnishing copies to other booksellers, for instance, when an international audience is intended; or by combining both methods. After a certain time, except for those copies still sitting in a bookseller's warehouse or bookshop, all copies will be in the hands of different owners, for it was and still is a rare phenomenon that somebody buys more than one copy for his or her personal collection. This is a fortiori the case for specific genres, such as topical works like advertisements, individual issues of newspapers, play bills, theatre programmes, or ordinances. It goes without saying that the impact of chance is at its pinnacle when all copies of a specific edition are distributed according to this general principle: editions are spread locally, regionally and internationally over as many owners or collections as there are copies.

Sooner or later, a fraction of all copies printed ends up in an institutional collection. Because there were always more printed books than anyone could possess, collecting was from the outset a very selective process. All libraries have limited means, room and people to handle acquisitions, and therefore exclude the bulk of what is offered on the market. Moreover, institutions usually refrain from acquiring so-called duplicates - i.e., a copy of an edition of a text already available in the collection. Of course, there are exceptions to this rule, but in most cases, those are clearly motivated, for instance by an important provenance, annotations, or other copy-specific features of the copy. In addition to this rule, institutions had a policy, which is in some places still operative, of weeding duplicates from their holdings. A famous example is the Sloane collection, which, although it was one of the corner stones of the British Museum, was dismantled in order to sell off all copies of which the institution already owned a copy. ${ }^{7}$ The result of both processes - that of selection and that of de-selection - is that only a fraction of the printing press's output ends up in institutional collections, and that possible duplicate copies are optimally re-distributed amongst them.

The third element is time. Time does not only devour its own children - for a book historian perhaps even worse - time also consumes books, sometimes just one by one, in other cases thousands at a time. Potential circumstances and modalities by which this happens have been described in detail, but their common denominator is the factor time. ${ }^{8}$ Use, fires, floods, theft, vermin,

7 On the Sloane collection see Alison Walker's contribution in this volume.

8 See Neil Harris, 'La sopravvivenza del libro, ossia appunti per une lista della lavandaia', Ecdotica, 4 (2007), pp. 24-65, where is also given a selective historiography of the phenomenon of the loss of books and its factors. 
fungal infections, censorship, abolition, deselection: the increase of the impact of each of those devastating factors is directly connected with time. Although each disaster wiping out a book or a collection of books can be accounted for, as a whole, the accumulation of calamities and catastrophes over the course of multiple generations is of an accidental nature.

As demonstrated by fig. 8.3, the combination of optimal divergence, of selective convergence, and of continuous loss, result in a random combination of surviving copies, some of which are preserved individually, some in private collections and some in institutional collections. Subsequently, copies kept in various institutional collections may be included in bibliographies such as the STCV.

The outcome of this process, in which the survival of copies is entirely random, can be virtually generated in a test corpus such as the ones used to produce figs. 8.1 and 8.2. It is instructive to consider the entire distribution of singletons, duplicates, triplets and so on, of a random sample in a similar corpus with the distribution in the corpus I derived from the STCV for the purpose of this chapter. fig. 8.4 shows the distribution of editions in a fictitious corpus of 20,000 editions, each of them with a print run of 150 copies; fig. 8.5 represents the distribution in the corpus derived from the STCV. I will discuss the composition of the latter corpus in detail in the next section.

Although fig. 8.5 has a much longer right tail, its right-skewed distribution is similar to that of fig. 8.4, which is the result of a verifiable and truly random sample.

\section{Corpus}

The corpus, which is the subject of analysis in the following sections, is based on the STCV, the online, retrospective bibliography for hand-press books printed or published in the Southern Netherlands in the early modern period. The STCV was modelled after the much earlier established STCN, the Short Title Catalogue, Netherlands, the online, retrospective bibliography for hand-press books printed or published in the Netherlands before 1801, as well as for books printed in Dutch outside the country's contemporary boundaries in the same period, Belgian books excepted. Since February 2000, the largest part of this deliberate lacuna in the STCN is in the process of being addressed. ${ }^{9}$

9 Not dealt with are Dutch editions printed in Wallonia, the southern, French-speaking part of present day Belgium. 


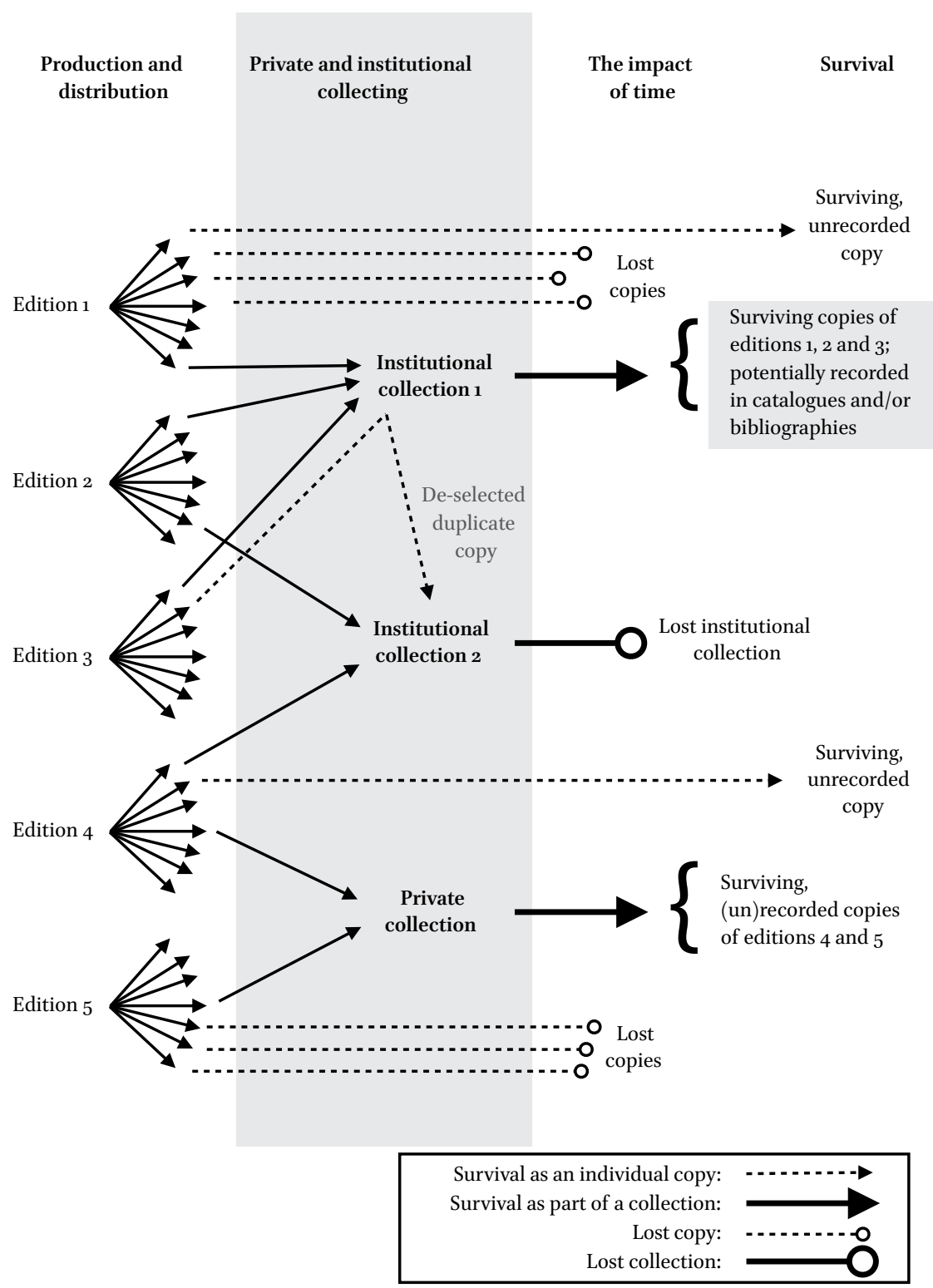

FIGURE 8.3 Diagram of the process of optimal divergence, selective convergence and continuous loss 


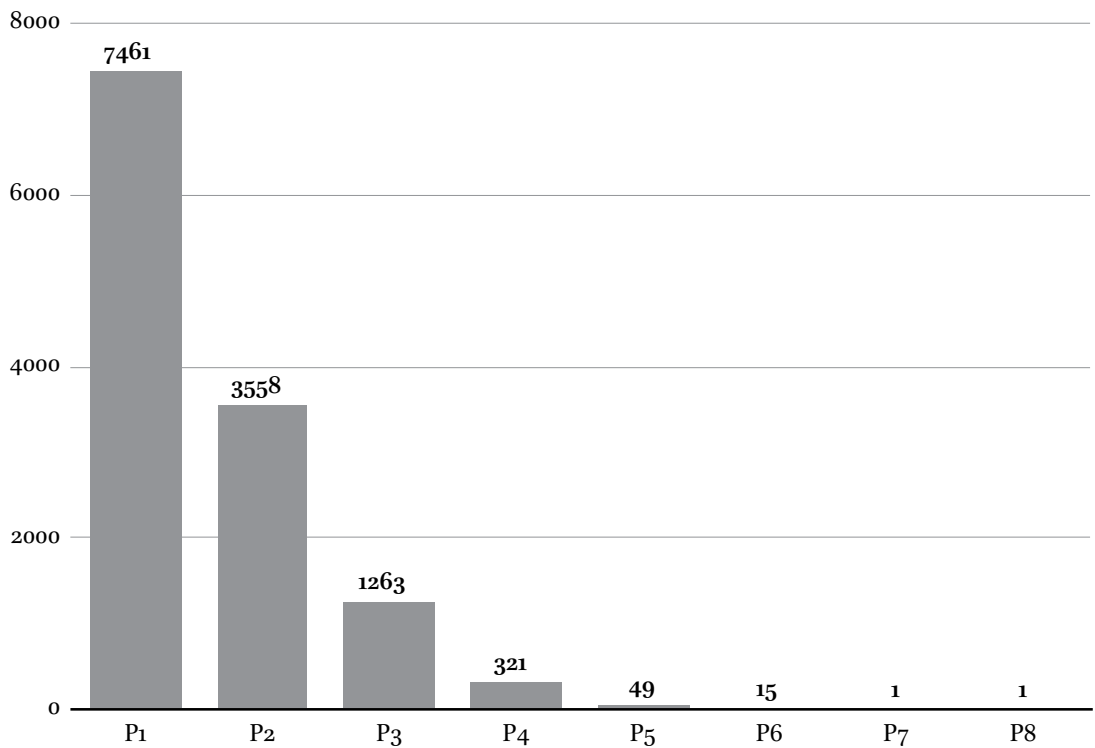

FIGURE 8.4 Distribution of editions in $1,2,3, \ldots, n$ copies based on a random sample of 20,000 items in a corpus of 20,0oo editions for which $a=150$

7000

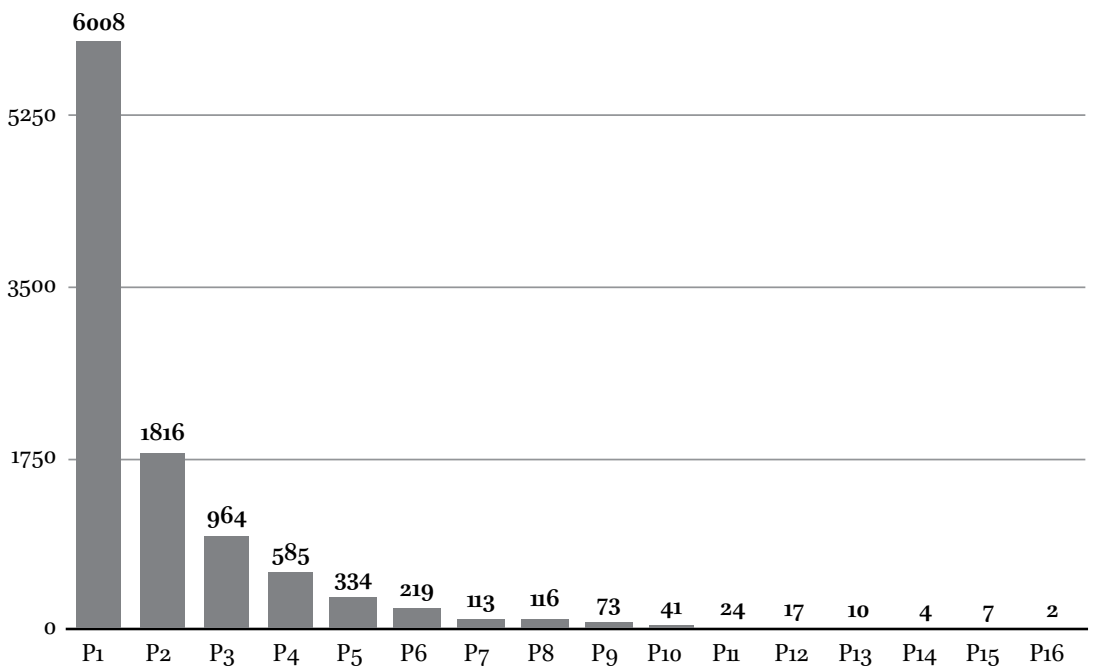

FIGURE 8.5 Distribution of editions ( $P 1$ through P16) in a corpus of seventeenth-century editions derived from STCV based on a download of 5 May 2015 
Here I will discuss those features that are most pertinent for the rest of this chapter. ${ }^{10}$ In principle, the scope of the STCV is limited to hand-press books from the Early Modern Period, and therefore most editions in the bibliography date from before 1801. For practical reasons, the focus was from the beginning on the seventeenth century, and, as a result, that period is, at present, described best. On 5 May 2015, the database contained 21,763 bibliographic descriptions of which 12,266 have publication dates between 1601 and 1700 (56.36\%). With 8,118 descriptions, the eighteenth century is second, but the coverage of this period is, as indicated by fig. 8.6, still less consistent. The weak coverage for the fifteenth and sixteenth centuries is compensated for by already existing bibliographies and projects for those periods, such as the Incunabula Short Title Catalogue hosted by the British Library (ISTC), Nijhoff and Kronenberg's bibliography of post-incunabula from the Low Countries (NK; 1501-1540), Belgica typographica (вт; 1541-1600), and the Universal Short Title Catalogue (USTC; describing all known pre-1601 editions), a project based at the University of Saint Andrews in Scotland. ${ }^{11}$

The geographic scope is Flanders, an anachronistic criterion, in principle only taking into consideration books printed in cities part of the present day Flemish Community and Brussels, thus excluding historical printing centres in the Nord de France (amongst others, Cambrai, Douai or Arras) and a number of cities now on Dutch soil (e.g., 's-Hertogenbosch). In addition to the main printing centres Antwerp, Ghent, Louvain and Brussels, hand-press books were produced in this period in Aalst, Audenaerde, Bruges, Courtrai, Dendermonde, Hasselt, Ypres, and Mechelen. In the eighteenth century small printing shops would open in Diksmuide, Temse, Tienen, Turnhout, Ostend, and Ronse.

Because the ordinary user cannot be expected to recognise foreign products bearing false, Flemish, imprints, the STCV also includes books falsely advertised as being printed, for instance, in Antwerp but in fact originating from abroad, such as many editions printed by the Catholic printer Christiaen

10 For a detailed description of both bibliographies, their scope and methodology, see Handleiding voor de medewerkers van de STCN (2nd edition, 's-Gravenhage, 1988), and Steven van Impe, Stijn van Rossem and Goran Proot, Handleiding voor de Short Title Catalogus Vlaanderen (2nd revised edition, Antwerp: Erfgoedbibliotheken Vlaanderen, 2005).

11 See Steven van Impe, Goran Proot and Susanna de Schepper, 'Beyond description. Bibliographic tools as "big data" for the study of Belgian hand-press books. With an example on the use of typographical ornaments, 1501-1540', De Gulden Passer, 92.1 (2014), pp. 103-124, especially $111-113$. 
3000

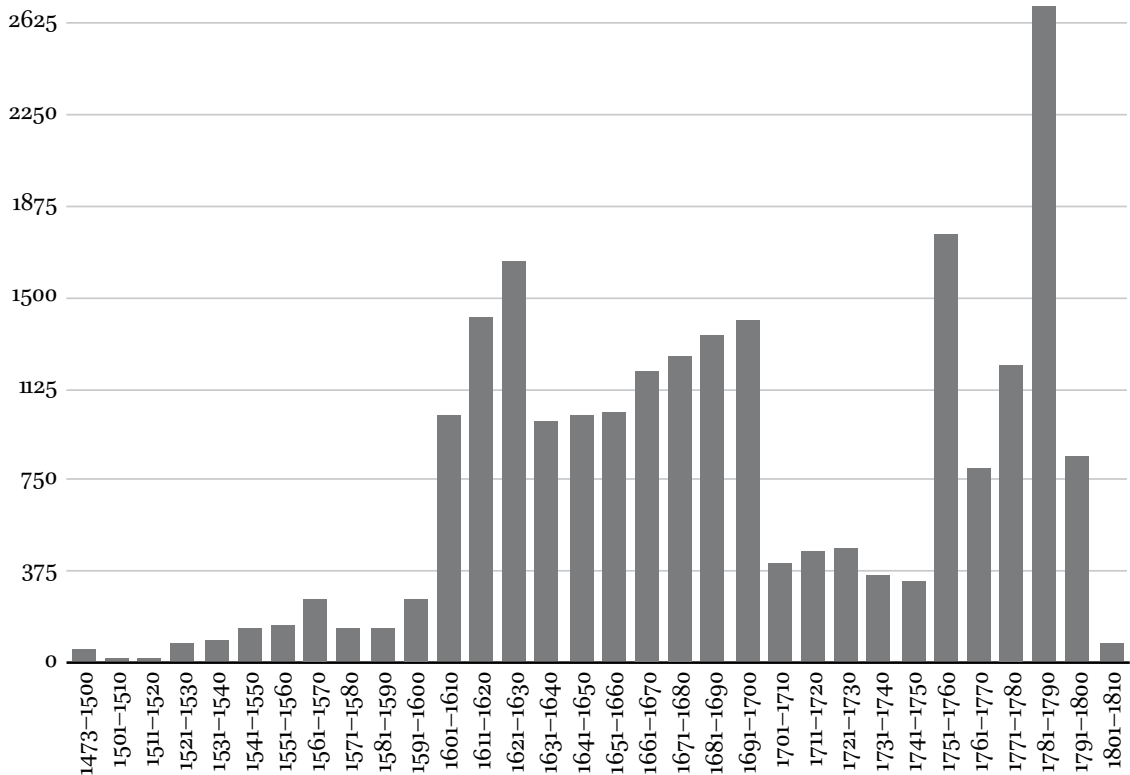

FIGURE 8.6 Distribution of editions in the STCV according to date of publication (some descriptions contain more than one date and appear more than once in this overview; status on 5 May 2015)

Vermey who was active in Leiden. ${ }^{12}$ Likewise editions without a place of publication but which are possibly or probably produced in the Southern Netherlands are included in the online bibliography. During the first phase of the project, only Dutch-language books were entered, but that criterion was abandoned after 2003. At present, the database contains publications in more than a dozen languages, the most important of which are, for the seventeenth century, Dutch $\left(6,15^{\circ}\right.$ editions), Latin $(4,930)$ and French $(1,529)$.

Like the STCN, the STCV excluded several categories of printed works, some on purely material grounds, others because they do not comply with the idea of what a 'book' should be. In the latter category, the bibliography does not include newspapers or journals. Before 2007, broadsides (texts printed on one side of a sheet only), were not entered either, but now they are. Atlases and books of prints - that is, books consisting of series of intaglio prints (copper

12 Paul Hoftijzer, 'Antwerpen of Leiden? Opkomst en ondergang van de Leidse katholieke uitgever en boekverkoper Christiaen Vermey (werkzaam 1704-1724)', De Gulden Passer, 93.1 (2015), pp. 37-58. 
engravings, etchings, or those combining both methods) - without parts printed with moveable type, are not included either.

Both STCV and its sister project STCN have some important qualities in common. Until now, the bibliographic descriptions in both bibliographies have always been based on the inspection of actual copies book in hand. Both projects use a so-called fingerprint to compare copies and to distinguish different editions. More than the STCN, the STCV pays attention to copy-specific features. Defects of inspected copies are always explicitly indicated at copy level. Also systematically indicated in the Flemish bibliography are binding mistakes and the fact that a copy is part of a Sammelband (in French: recueil factice), meaning that it is bound with other texts in print or manuscript in one physical volume. The decision to systematically indicate the latter feature of actual copies turns out to be extremely useful in understanding loss factors of printed books.

For all books, the STCN records the bibliographic format, mostly followed by extensive collations, and so does the STCV, but in general, the Dutch project does not collate individual parts of most multi-volume works published by the same printing shop. In the STCV, all books are always entirely collated, and if a book contains printed material out of collation, that fact is mentioned in the description, either on the edition or copy level, or, if pertinent, on both. Another difference is that the Flemish bibliography always includes a pagination (or foliation) statement. On the basis of the bibliographic format and the collation, it is possible to calculate how many sheets are required to print one copy of an edition. Also this information turns out to be crucial for a better understanding of the book trade, and of survival and loss, and for that reason this number has recently been added to the descriptions.

Both the STCN and the STCV systematically add subject terms and typographical descriptors to descriptions. The lists for each category of terms and descriptors are limited and well-defined. Unlike the STCN, there is no maximum number of subject terms which can be added to an entry in the STCV. Also, the list of typographical descriptors in this database is slightly more intricate than that of the STCN, distinguishing, for instance, the use of different colours of ink (usually red) on the title page and in the body of the work. For a correct interpretation of the use of subject terms and descriptors users should consult the manual, because their application may differ from term to term. The appearance of civilité type in a work, for instance, is always signalled by that descriptor, but for italics, this is only the case when a substantial part of the text is printed in italics - and what is to be understood under 'substantial' in turn is a judgement call. But in principle, all descriptions in both online tools are produced by well-trained bibliographers and reviewed by a senior 
bibliographer. In addition, the adding of extra copies to an existing description is always based on autopsy and results in a complete review of the record. On 5 May 2015, 33.96\% of all descriptions in the STCV referred to more than one copy - two thirds of the editions are singletons.

More than 37,700 images of typographic and engraved title pages, colophons, printer's devices, author's portraits and of specific fingerprint positions facilitate the work of bibliographers and other users. This image collection, together with numerous deep links to copies digitised in full, constitutes a magnificent source for further research.

As a result, the STCV can be considered as a very systematic, coherent and precise bibliographic tool which can be used for metadata analysis. For the purpose of this survey, I concentrated on seventeenth-century book production only, because this period is still the core of the bibliography. Fig. 8.6 shows 12,312 bibliographic records for this century, spread over ten decades. For this survey, I selected 10,339 editions from this period, which, all together, refer to 21,566 individual copies from 24 different institutional collections.

The selection is based on a download of the STCV which dates from 5 May 2015. Not all editions could be used. In total, 1,913 bibliographic descriptions were excluded on one or more grounds. The dataset used for my analysis consists only of descriptions which can be dated between 1 January 1601 and 31 December 1700 . Editions potentially printed before or after this period are excluded. In some cases, an edition bears two (or more) dates. From the moment that one of those dates falls outside the temporal scope of this survey, the edition is taken out of the dataset. Also excluded are editions produced outside the present day borders of Flanders, or which suggest a foreign origin, as well as editions with fictitious or false places of publication, unless a Flemish origin is certain. This is also the case when a book bears more than one imprint: it is excluded from the analysis as soon as an imprint certainly is or may be outside the scope of the survey. Furthermore, the dataset does not contain bibliographic descriptions with unclear bibliographic formats or which lack collations, as those elements are indispensable for the analysis. Finally, multi-volume editions, mentioning two or more collations in one bibliographic record, are not considered. This is the case for 395 seventeenthcentury records, representing just over $3 \%$ of all records from this period.

As a result of this filtering, the final selection for this survey contains $83.97 \%$ of all records which initially turned up in a simple search for all seventeenthcentury descriptions. With 10,339 records, this cleaned-up corpus is still large enough to perform fairly detailed analysis, even of specific subsets, if only they consist of about 1,0oo records or over. As indicated before, much smaller samples may pose problems of reliability. 
In order better to understand the nature of the corpus, it is important to consider the origin of the copies in it. The majority of the copies are kept in eleven collections, in nine of which all seventeenth-century books from the Southern Netherlands have been processed. Those nine are the Erfgoedbibliotheek Hendrik Conscience in Antwerp (4,540 copies), Ghent University Library (5,424), Public Library Bruges 'De Biekorf' (947), Antwerp University Library (747), the Library of the City Archives in Mechelen (628), the Folger Shakespeare Library in Washington, DC (497), the Library of the City Archives in Turnhout (307), the Provincial Library Limburg (302), and the Library of the City Archives in Oudenaarde (150). Almost fully processed is the collection of Ruusbroecgenootschap Antwerp $(2,581)$ - only a part of the Latin editions needs to be entered. Thus far only a selection of the collections kept at the University Library of KU Leuven in Louvain (Central Library: 2,358; Maurits Sabbe Library: 2,507) have been processed. Selected copies were entered from thirteen more collections, located in Belgium or abroad. In Belgium, 440 copies from the Museum Plantin-Moretus in Antwerp were added, 34 copies from the Aartsbisschoppelijk Archief Mechelen-Brussels, nine from the Library of the Royal Museum of Fine Arts in Antwerp, three from the Royal Library in Brussels, and two from the library at the Abbey of Tongerlo. In France, nine copies from the Bibliothèque Mazarine in Paris were entered, four from the Bibliothèque municipal de Lyon, and two from the Bibliothèque Sainte-Geneviève (Paris). In the Netherlands 38 copies from the National Library of the Netherlands found their way to the database, fifteen from Special Collections at the University of Amsterdam, and one from the Thysiana in Leiden. Finally, the selection contains two copies from Trinity College Dublin (Ireland), and one from the University Library in Basel (Switzerland).

Obviously, there are many more institutions whose collections should be added to the STCV. The fact that copies from the Museum Plantin-Moretus are only entered piecemeal, and that the Royal Library in Brussels is not an official partner of the project, constitutes an important lacuna. While the latter collection is downright vast, and not only for Brussels imprints, the former is a paramount collection for the output of Plantin and his successors as well as for Antverpiensia in general.

Fortunately, this absence is partly compensated for by three important Antwerp collections, which also collect Antverpiensia in addition to other works. Both the Erfgoedbibliotheek Hendrik Conscience (EHC) and Ghent University Library are very rich collections for Flandrica (texts produced in or related to the Southern Netherlands), in addition to books printed in the city where those libraries are located. The same goes for most other libraries in the 
list: as 'De Biekorf' in Bruges focuses on editions from Bruges, the Library of the City Archives in Mechelen owns an incomparable collection of Mechliniensia, ${ }^{13}$ and the libraries at the $\mathrm{KU}$ Leuven collect editions produced in Louvain and the academic community in this city. And even though the institutional collections in Turnhout, Hasselt (Provincial Library Limburg), and Oudenaarde own much smaller collections, their specific focus on regional works adds much value to the STCV as a virtual meta-collection.

At present, one can only speculate on the effects of the absence of a number of important national collections in the STCV. And as the example of the Folger Shakespeare Library in Washington, DC, clearly demonstrates, collections outside Belgium in some cases contain a relatively large part of unica, too (see table 8.2). On the other hand, this does not affect the validity of the estimations, as those are based on a very large and cleaned-up corpus of reliable metadata.

TABLE 8.2 Seventeenth-century editions listed in the STCV, by library

\begin{tabular}{lcccc}
\hline Collection & Editions & Copies & Unica (ed.) & $\begin{array}{l}\text { Ratio unica/ } \\
\text { editions (\%) }\end{array}$ \\
& & & & 51.16 \\
\hline E HC Antwerp & 4,038 & 4,540 & 2,066 & 42.60 \\
UL Gent & 4,037 & 5,424 & 1,720 & 28.90 \\
RG Antwerp* & 1,886 & 2,581 & 545 & 23.15 \\
KU Leuven: MSL* & 1,814 & 2,507 & 420 & 22.07 \\
KU Leuven: CL* & 2,012 & 2,358 & 444 & 24.81 \\
PL Bruges: De Biekorf & 806 & 947 & 200 & 12.87 \\
UL Antwerp & 614 & 747 & 79 & 29.28 \\
CA Mechelen & 543 & 628 & 159 & 28.87 \\
Folger & 478 & 497 & 138 & 19.80 \\
MPM Antwerp* & 399 & 440 & 79 & 12.14 \\
CA Turnhout & 280 & 307 & 34 & 20.45 \\
PL Limburg & 269 & 302 & 55 & 15.97 \\
CA Oudenaarde & 144 & 150 & 23 & \\
& & & &
\end{tabular}

* Collection of seventeenth-century editions not yet fully processed.

13 Cf. Goran Proot, Diederik Lanoye and Willy Van de Vijver (eds.), Gedrukte stad. Drukken in en voor Mechelen 1581-180o (Brugge: Van de Wiele, 2010); Diederik Lanoye, 'De Mechelse drukpers voor 180o',Jaarboek voor Nederlandse boekgeschiedenis, 16 (2009), pp. 131-150. 


\section{Analysis}

Before I present the results of the analysis, it is good to think about the nature of the corpus again. Analysed are seventeenth-century records of editions in the STCV, which were printed or published in the Southern Netherlands. Multivolume editions are excluded, as well as descriptions with a dubious format or collation. The objects in the final corpus include hand-press books only, which are (at least partly) produced with moveable type. The descriptions are based on copies held in national and to some extent international, institutional collections, each of which maintain a specific selection and de-selection policy. This implies that the estimates of the corpus and of its subsets pertain only to an estimated total population of hand-press works with similar features. In other words, the results do not say anything about specific objects which fall outside the collection policy of institutions, or which have an unclear, potential non-Flemish origin, or which may be produced or sold beyond the seventeenth century.

In this section, I present only a selection of the results of estimates based on specific bibliographic features. In the course of this survey, many more were tested, but did not result in relevant findings. In other cases, subsets of records which could be analysed turned out to be too small to generate sound results. The results based on subsets consisting of less than 1,00o records are only mentioned if they seem clearly to indicate an important trend, but the actual estimates based on those small subsets should be interpreted with great caution.

The selection consists of 10,339 editions in 20,235 copies. As demonstrated by fig. 8.5, 6,oo8 editions are present in one copy only (58.11\%). About $17.57 \%$ of the editions are recorded in two copies, $9.33 \%$ are triplets, $5.66 \%$ are quadruplets, and $3.23 \%$ of all editions are known in five copies. 219 editions or $2.12 \%$ of the corpus are recorded in six copies, $1.09 \%$ in seven, and $1.12 \%$ in eight copies. From here, the numbers decrease even further and represent less than 1 per cent of the total number of editions. 73 editions have nine copies, 41 have ten, 24 have eleven, 17 have twelve, and 10 have 13 copies. There are only four editions recorded in 14 copies, only seven with 15 copies, and two with 16 copies. The corpus contains one edition each with 17, 18, 19, 23, and 24 copies, and finally, there is one book preserved in 32 copies. It is a lavishly illustrated quarto on large paper, the Af-beeldinghe van d'eerste eevwe der societeyt Iesv, a Dutch translation by Laurentius Uwens and Adriaan Poirters of the Imago primi saeculi, both of which were published by the Plantin Press. In 1640, the Latin edition was printed as a folio in a run of 1,050 copies, each of which cost 
18 gulden, making a total of 18,90o gulden (ill. 8.3) ${ }^{14}$ The sTCV records ten copies of this edition (ill 8.1). Although the imprint of both editions clearly mentions 1640 , the print information of the Dutch edition is recorded in the papers of the firm under the year 1641, where is noted that the Af-beeldinghe was produced as a quarto in 1,525 copies, which were sold at 9 gulden each (ill. 8.2). ${ }^{15}$

On the basis of singletons and duplicates and an arbitrary print run of 500, the formula for the estimation of editions returns a loss rate of $54.59 \%$. In other words, the 10,339 recorded editions represent $45.41 \%$ of all editions with the same characteristics of the total population of editions, which, as a result of this exercise, can be fixed at 22,767 editions. This is of course an estimate, but, according to simulations with a comparable fictitious corpus, probably a fairly precise one (see fig. 8.2).

\section{Sheet Counts}

That both editions related to the centenary of the Jesuit order mentioned in the previous section turn out to be expensive books is not a coincidence. Their price is not only the result of the inclusion of a large amount of copper engravings, but also of the number of sheets required to produce a copy. For each copy of the quarto edition in the vernacular, 91 full sheets of paper were needed, while the Latin edition, which was printed as a folio, required 246 sheets per copy. For unillustrated books, the number of sheets of paper per copy - sometimes indicated as 'edition sheets' 16 - is the most important indicator of an average book's production cost. ${ }^{17}$ Printers calculated the production cost by sheet, irrespective the number of pages printed on it. Generally speaking, there is as much work and material involved in the production of an

\footnotetext{
14 MPM м 39, f. 39v, and M 321, f. $108 r$.

15 мРм м 39, f. 4or, and м 321, f. 1ogr.

16 For instance David L. Gants, 'A quantitative analysis of the London book trade 1614-1618', Studies in Bibliography, 55 (2002), pp. 185-213: "I have employed the edition sheet as the base unit for measuring printing-house output. Bibliographers have employed this term for different concepts, but I take it to mean the number of sheets in an exemplar volume used as a measure of the relative amount of work required to produce the complete run of that volume" (p. 186).

17 In the second half of the sixteenth century, the cost of paper amounted to 30 to $40 \%$ of the total production cost of books in Geneva, see H.-J. Bremme, Buchdrucker und Buchhändler zur Zeit der Glaubenskämpfe. Studien zur Genfer Druckgeschichte 1565-1580 (Geneva: Droz, 1969), p. 32, as cited by Gilmont in his 'Livre, bibliographie et statistiques', p. 8o1, footnote 1 .
} 


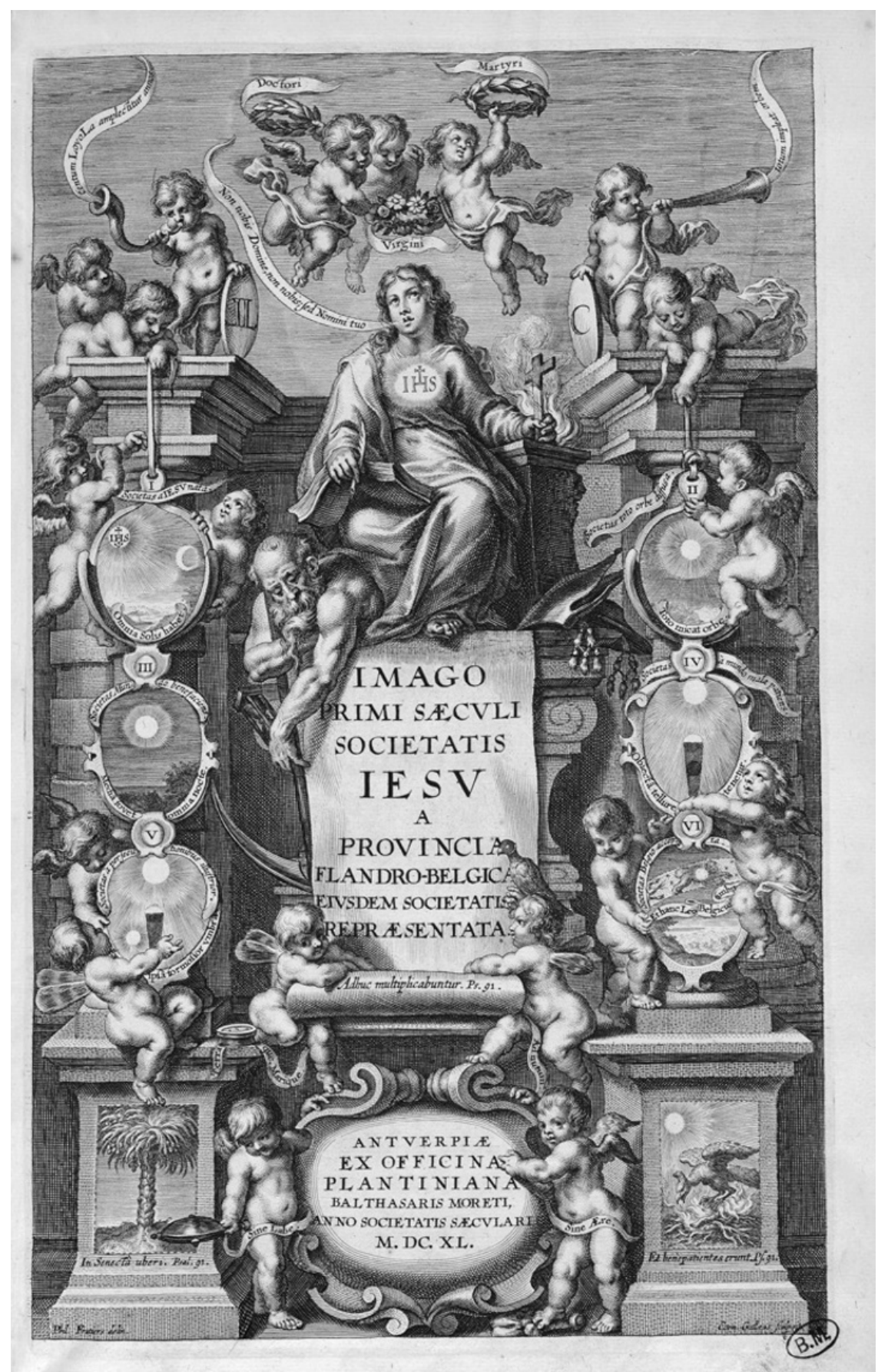

Illustration 8.1 Imago primi saeculi Societatis Iesu a Provincia Flandro-Belgica eiusdem Societatis reprcesentata (Antwerp: Officina Plantiniana; Balthasar Moretus, 1640)

(C) Bibliothèque Mazarine, Paris $\left[2^{\circ} 54172 \mathrm{e} e x\right]$ 


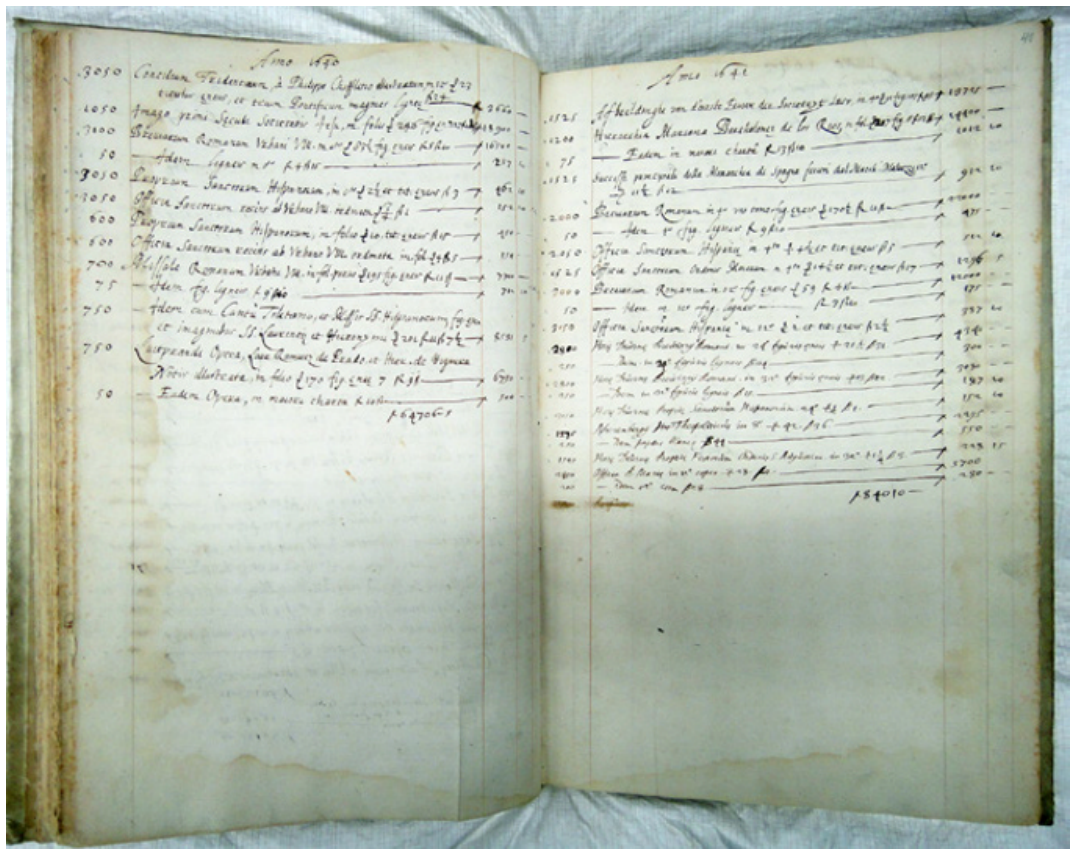

illustration 8.2 M39, Museum Plantin-Moretus, Antwerp, ff. 39v-4or

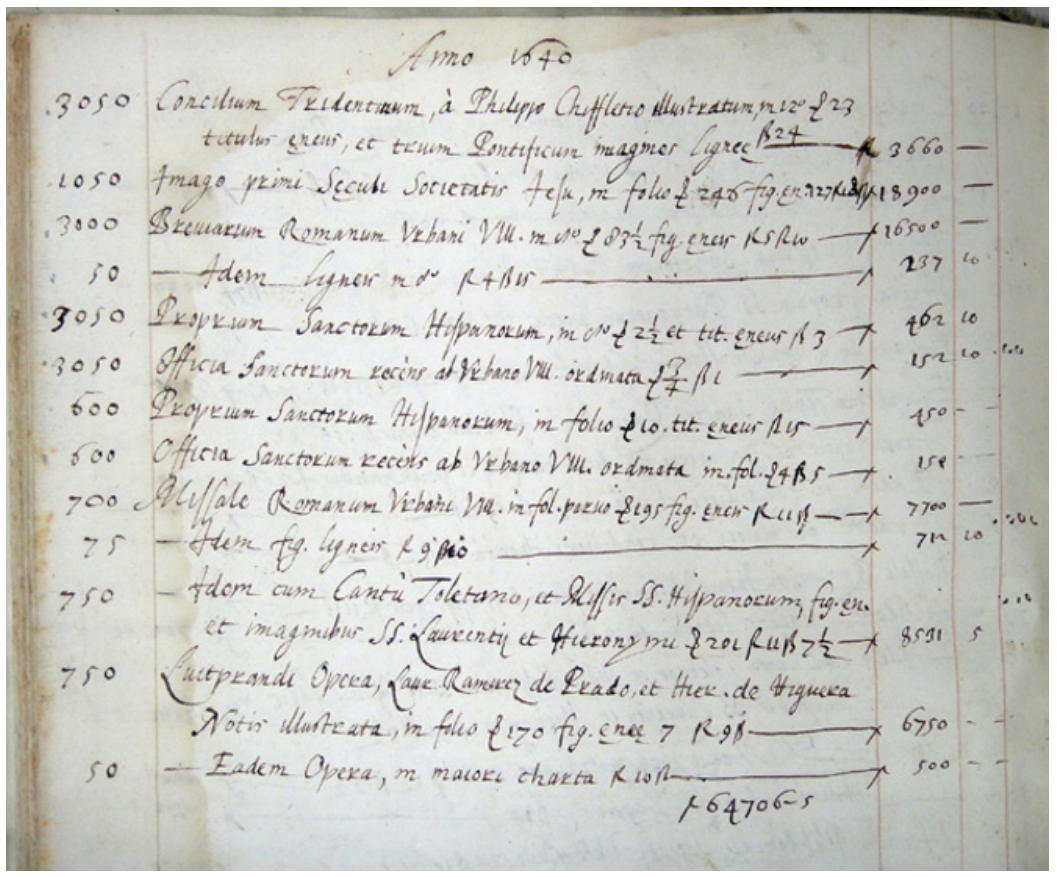

illustration 8.3 M39, Museum Plantin-Moretus, Antwerp, f.39v (detail) 
octavo book counting 16 pages as there is for a duodecimo of 24 pages. For both books a compositor has to compose an inner as well as an outer forme, for both books pressmen have to mount one sheet on the press, to ink the type and to print the sheet on both sides.

Table 8.3 and fig. 8.7 clearly indicate that there is a direct relationship between the number of sheets per copy and survival rates of books. For all editions in the dataset I calculated the number of sheets per copy, information which can easily be derived by dividing the total number of leaves by the bibliographic format. In an octavo book 8 leaves (or 16 pages) make one sheet, in a duodecimo 12 leaves (or 24 pages). Table 8.3 shows ten subsets or categories, which are based on the number of sheets per copy. The first category consists of books for which one sheet or less paper is required to produce one copy. The second category is for books with more than one and up to two sheets per copy, the third category for books counting twice as many sheets, and so on..$^{18}$ Categories 8, 9 and 10, for books consisting of more than 64 sheets per copy are marked with a star. They are mentioned here for completeness only - the numbers on which the estimates are based are too weak to be very reliable. For each subset, table 8.3 enumerates the number of singletons $\left(\mathrm{P}_{1}\right)$, of duplicates $\left(\mathrm{P}_{2}\right)$, and the total number of editions $\left(\mathrm{N}_{\text {found }}\right)$. Based on those numbers, the fraction of found $\left(\mathrm{P}_{\text {found }}\right)$ and of lost $\left(\mathrm{P}_{\text {lost }}\right)$ editions is calculated (here rendered as a percentage), as well as the nominal number of

TAB LE 8.3 Found and lost editions according to sheet counts

\begin{tabular}{|c|c|c|c|c|c|c|c|c|c|c|c|}
\hline & $\leq \mathbf{1}$ & $\mathbf{1} \leq \mathbf{2}$ & $2 \leq 4$ & $4 \leq 8$ & $8 \leq 16$ & $16 \leq 3^{2}$ & $32 \leq 64$ & $64 \leq 128^{*}$ & $128 \leq 25^{*}$ & $25^{6} \leq 5^{12}{ }^{*}$ & Total \\
\hline $\mathrm{P}_{1}$ & 2,076 & 713 & 699 & 696 & 712 & 555 & 244 & 140 & 135 & $3^{8}$ & 6,008 \\
\hline $\mathrm{P}_{2}$ & 145 & 138 & 202 & 263 & 381 & 339 & 176 & 91 & 61 & 20 & 1,816 \\
\hline $\mathrm{P}$ (found) in $\%$ & 13.06 & 32.14 & 43.94 & 53.08 & $65 \cdot 74$ & 70.55 & 76.39 & 72.77 & $59 \cdot 53$ & 65.13 & $45 \cdot 41$ \\
\hline $\mathrm{P}($ lost $)$ in $\%$ & 86.94 & 67.86 & 56.06 & 46.92 & 34.26 & $29 \cdot 45$ & 23.61 & 27.23 & 40.47 & 34.87 & $54 \cdot 59$ \\
\hline $\mathrm{N}($ found $)$ & 2,268 & 968 & 1,113 & 1,293 & 1,605 & 1,472 & 782 & 410 & 328 & 100 & 10,339 \\
\hline $\mathrm{N}($ lost $)$ & 15,098 & 2,044 & 1,420 & 1,143 & 836 & 614 & 242 & 153 & 223 & 54 & 12,428 \\
\hline $\mathrm{N}($ total $)$ & 17,366 & 3,012 & 2,533 & $2,43^{6}$ & 2,441 & 2,086 & 1,024 & $5^{63}$ & $55^{1}$ & 154 & 22,767 \\
\hline
\end{tabular}

* Weak numbers, supplied here for comparison only.

18 This method was, to my knowledge, for the first time used by Diederik Lanoye in 'Mechelse drukkers en Mechelse drukken tijdens het ancien régime', in Goran Proot, Diederik Lanoye and Willy Van de Vijver (eds.), Gedrukte stad. Drukken in en voor Mechelen 1581-180o (Bruges: Van de Wiele, 2010), pp. 14-51. 


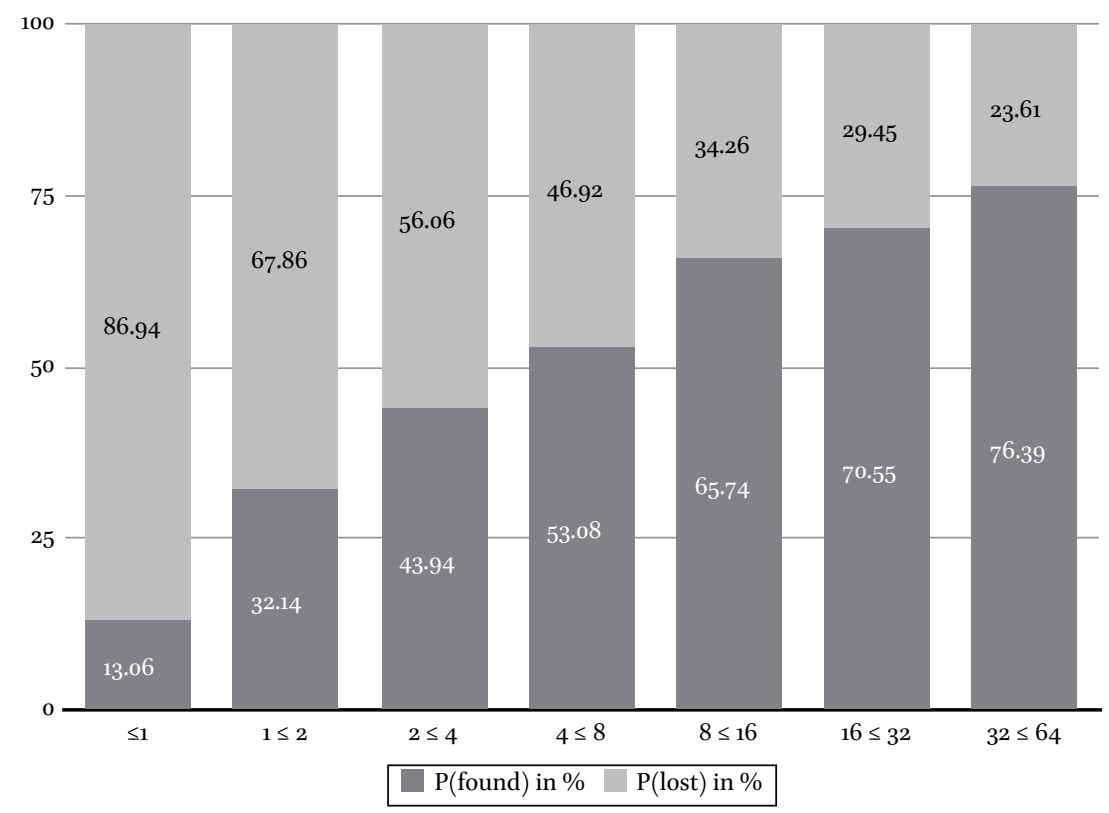

FIGURE 8.7 Percentage of estimated found and lost editions according to the number of sheets required to produce one copy of an edition

editions this estimate should represent $\left(\mathrm{N}_{\text {lost }}\right)$, and finally the total number of editions in this category $\left(\mathrm{N}_{\text {total }}\right)$, adding up $\mathrm{N}_{\text {found }}$ and $\mathrm{N}_{\text {lost }}$. The print run $(a)$ is fixed at 500 .

\section{Bibliographic Format}

In addition to the regular bibliographic formats, the corpus includes 104 works designed in an oblong format: as an oblong broadside (12), folio (4), quarto (4), octavo (32), duodecimo (4), sextodecimo (33), and fifteen more in other oblong formats. In the text, only four formats will be discussed: folio, quarto, octavo and duodecimo (also called $12^{\text {mo }}$ or 'twelvemo'). From a quantitative point of view those four are the most important formats as far as institutional collections are concerned. Combined they represent $93.39 \%$ of all editions in this survey. For broadsides, $16 \mathrm{mos}$ and smaller formats, the sample size is too small for precise application of the model. Some of the results are counter-intuitive. Books in octavo format in this survey are preserved best. It is estimated that the sample represents $62.51 \%$ of all octavos produced. Duodecimos are next, with survival rates of $57.00 \%$, and only third come folios, physically the tallest and widest volumes. Traditionally, this is the format thought of as the best preserved, but 
that conclusion seems not to hold up as folios show a loss rate of about $54.80 \% .{ }^{19}$ The format most prone to loss, however, is the quarto: according to the estimates, only about one in three editions are present in the sample (33.97\%); almost two thirds of the production with similar features to the quarto books in this survey remain unrecorded.

On average, folios consist of 93.70 sheets per copy, which, according to table 8.3, should be very beneficial for survival rates. ${ }^{20}$ Of the three other categories, octavos are the books with the highest number of sheets per copy, i.e. $17.5^{2}$ sheets. ${ }^{21}$ This is significantly more than the average quarto (12.69) or duodecimo (10.89). ${ }^{22}$

TABLE 8.4 Bibliographical format

\begin{tabular}{|c|c|c|c|c|c|c|c|c|c|c|}
\hline & Broadside & 20 & 4to & 8vo & $12 \mathrm{mo}$ & $16 \mathrm{mo}^{*}$ & $18 \mathrm{mo}^{*}$ & 24mo* & $3^{2 m o}{ }^{*}$ & Total \\
\hline $\mathrm{P}_{1}$ & 133 & 616 & 2,698 & 1,153 & 1,006 & 222 & 45 & 120 & 8 & 6,008 \\
\hline $\mathrm{P}_{2}$ & 7 & 185 & 559 & $5^{65}$ & 424 & 21 & 8 & 43 & 1 & 1,816 \\
\hline $\mathrm{P}($ found $)$ in $\%$ & 10.01 & $45 \cdot 2$ & 33.97 & $62.5^{1}$ & 57 & 17.27 & $29 \cdot 96$ & 51.21 & 22.15 & $45 \cdot 41$ \\
\hline $\mathrm{P}($ lost $)$ in $\%$ & 89.99 & 54.8 & 66.03 & $37 \cdot 49$ & 43 & 82.73 & 70.04 & 48.79 & 77.85 & $54 \cdot 59$ \\
\hline $\mathrm{N}$ (found) & 144 & 1,157 & 3,960 & 2,676 & 1,863 & 262 & 61 & 195 & 10 & 10,339 \\
\hline $\mathrm{N}$ (lost) & 1,295 & 1,403 & 7,698 & 1,605 & 1,406 & 1,255 & 143 & 186 & 35 & 12,428 \\
\hline $\mathrm{N}($ total $)$ & 1,439 & 2,560 & 11,658 & 4,281 & 3,269 & 1,517 & 204 & 381 & 45 & 22,767 \\
\hline
\end{tabular}

*Weak numbers, supplied here for comparison only.

19 See, for instance, Suarez, 'Towards a bibliometric analysis of the surviving record', p. 57, where the author refers to 'disproportionately high survival rates of large-format books', and 'Roger Stoddard's Law' ('Bigger books linger longer; little books last least'). "Folios and, to a lesser extent, quartos tend to persist; octavos and duodecimos - not only because of their size, but also because of the way they are read and used - commonly perish."

20 The distribution of sheets required to produce one copy of a folio recorded in the sample is the following: $\leq 1$ sheet per copy: $259 ; 1 \leq 2$ sheets per copy: $27 ; 2 \leq 4: 45 ; 4 \leq 8: 64 ; 8 \leq 16$ : $81 ; 16 \leq 32: 59 ; 32 \leq 64: 75 ; 64 \leq 128: 152 ; 128 \leq 256$ : $110 ;$ and $256 \leq 512: 100$.

21 The distribution of sheets required to produce one copy of an octavo in the sample is the following: $\leq 1$ sheet per copy: $186 ; 1 \leq 2$ sheets per copy: $137 ; 2 \leq 4: 268 ; 4 \leq 8: 377 ; 8 \leq 16$ : 537 ; $16 \leq 32: 711 ; 32 \leq 64: 432 ; 64 \leq 128: 28 ; 128 \leq 256$ : 0 ; and $256 \leq 512: 0$.

22 The distribution of sheets required to produce one copy of a quarto is the following: $\leq 1$ sheet per copy: 1,$415 ; 1 \leq 2$ sheets per copy: $587 ; 2 \leq 4$ : $560 ; 4 \leq 8: 393 ; 8 \leq 16: 278 ; 16 \leq 32$ : 229; $32 \leq 64: 250 ; 64 \leq 128: 217 ; 128 \leq 256$ : 31 ; and $256 \leq 512$ : 0 . For duodecimos: $\leq 1$ sheet per copy: 147; $1 \leq 2$ sheets per copy: $148 ; 2 \leq 4$ : 190; $4 \leq 8$ : 352; $8 \leq 16$ : $576 ; 16 \leq 32: 431 ; 32 \leq 64$ : 19; $64 \leq 128$ : 0 ; $128 \leq 256$ : 0 ; and $256 \leq 512$ : 0 . 
For the sixteenth century, octavo is the most frequently recorded book format across all countries $(39.71 \%)$, immediately followed by quarto $(36.77 \%) .{ }^{23}$ Until about 1525, the latter format outnumbered all others (fig. 8.8). In the 1530s, the majority of publications appear in octavo, which remains the case until the last decade of the sixteenth century, when quarto takes the lead again. Table 8.4 indicates that the quartos remain, in absolute numbers, the most important format for the seventeenth-century Southern Netherlands. The

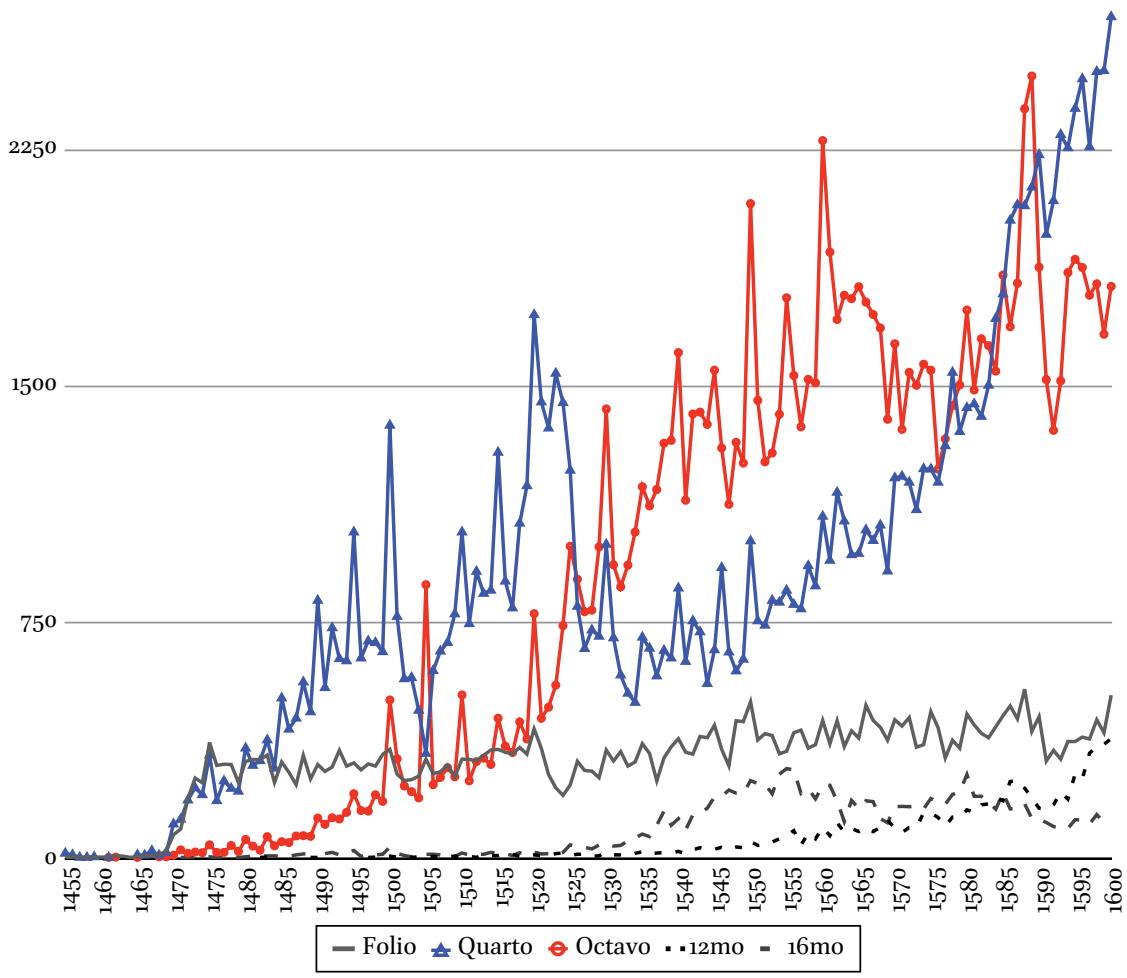

FIGURE 8.8 Number of folios, quartos, octavos, duodecimos and sedecimos per year as recorded in the USTC (searches performed 6 April 2015)

23 Numbers based on searches performed 6 April 2015 in the Ustc database. Compare the data presented by Jan Materné for liturgical books produced in the period 1590-1650 for the Officina Plantiniana: 'The Officina Plantiniana and the dynamics of the CounterReformation, 1590-1650', in Simonetta Cavaciocchi (ed.), Produzione e commercio della carta e del libro secc. XIII-XVIII (Prato: Le Monnier, 1992), pp. 481-49o, here p. 485 (graph 2). 
spikes in the period $1515^{-1525}$ for quartos in fig. 8.8 indicate how this format is related to specific genres, such as pamphlets, which were massively used in the polemic between Catholics and Protestants in this period.

The quarto is a format which lends itself to swift publication of pamphlets and other ephemeral genres, such as theatre programmes or academic theses, or other texts requiring rapid publication and distribution, such as ordinances and placards. Those text genres have in common that they constitute usually rather slim publications, whose information value expires relatively quickly. Thereafter, those publications become obsolete and tend to disappear more quickly than other books. For theatre programmes ordered by the Flemish Jesuits between 1575 and 1773, which are almost always published as quartos, the survival rate is as low as $20.5 \%{ }^{24}$

\section{Typographical Features}

The Short Title Catalogue Flanders distinguishes two types of title page: those which contain at least partly printing in relief, and those which are produced using copper plates only. ${ }^{25}$ In addition, 344 editions in this survey have no title page or lack a title page, but this category is not taken into account for the calculations presented in table 8.5. Compared to the overall estimation of lost editions throughout the dataset, the category of editions with a typographical title page is slightly better preserved: $50.11 \%$, which is almost $5 \%$ more than the overall average $(45.41 \%)$. Spectacular are the results for works with an engraved title page. Presumably, the corpus describes three quarters of the editions with this feature. The explanation for this is fairly simple. Works with engraved title pages count on average 63.13 sheets per copy. For works with typographical title pages this number is three times lower (21.10 sheets per copy). The latter number is very close to the overall average sheet count of all editions combined in this survey (22.36 sheets per copy).

24 Proot and Egghe, 'Estimating editions on the basis of survivals', p. 165. The economic importance of this kind of publication is underpinned by the fact that printers and commissioning bodies such as the Jesuits went through the trouble of formulating framework agreements for the production of theatre programmes, cf. Goran Proot, 'The importance of jobbing printing. A framework agreement between the Ghent Jesuits and the printer Baudewijn Manilius for the production of theatre programmes (1664)', Jaarboek voor Nederlandse boekgeschiedenis, 21 (2014), pp. 89-112.

25 Title pages combining intaglio and relief printing receive the descriptor 'typographic title page'. 


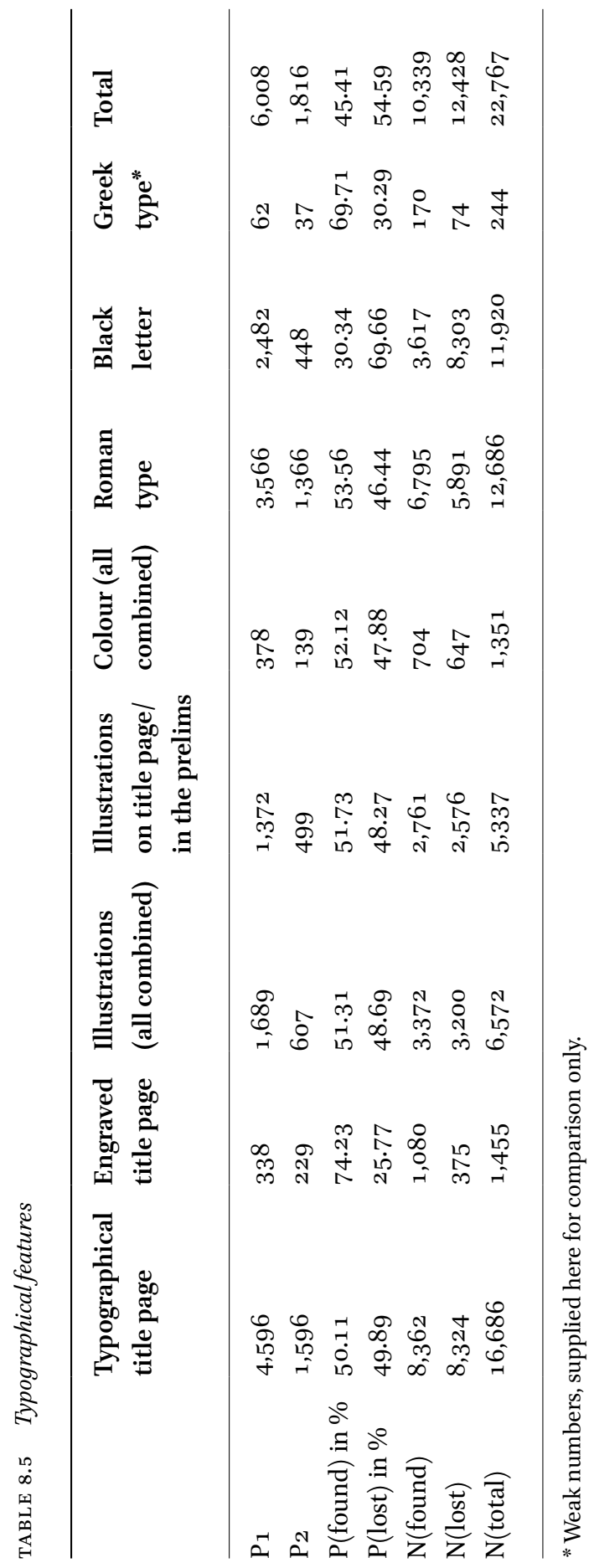


Engraved title pages are most frequent in octavos (329 editions in this survey), followed by duodecimos (259), folios (203), and quartos (164) - the rest of the editions with a frontispiece are spread over other bibliographical formats (125). This observation seems to suggest that the presence of an engraved title page has an important impact on the survival rate of specific formats, but in absolute numbers, this category represents only about one tenth of the entire dataset ( 1,080 versus 10,339 editions).

With the exception of engraved title pages the presence of illustrations has no important impact on survival rates, whether they figure in the prelims only, or turn up elsewhere in the book, in or out of collation. Neither does the use of different colours anywhere in the publications seem to be important for survival.

Seventeenth-century editions with text set in roman type have estimated survival rates which are about $8 \%$ higher than the average edition in the entire dataset. In contrast, works with text in black letter show bad survival rates: according to the stochastic model, only $30.34 \%$ of publications with this typographical feature seem to be present in the corpus. Although the absolute numbers for works mainly set in ancient Greek are too weak to be conclusive, the tentative outcome is illuminating, as it shows opposite numbers: almost seven in ten editions should be recorded, and only three are currently not located. This seems to suggest that collections are more complete for publications of the intellectual elite (Greek, Latin) than for those for more regional and local audiences which are printed in the vernacular (Dutch), but this conclusion requires some qualification. Works with text in roman type consist, on average, of 28.57 sheets per copy, while those in black letter count only 11.33 sheets per copy. With 49.88 sheets per copy, works in ancient Greek are the most expensive in terms of paper usage. As in the case of works with engraved title pages, both factors - type and size - reinforce one other.

\section{Target Language}

Works in Latin are much better preserved in institutional collections which contribute to the STCV and the dataset under consideration (table 8.6). Almost six in ten editions are present in the corpus. Works in vernacular languages have weaker survival rates: Dutch-language books only $36.58 \%$. Frenchlanguage books, on the other hand, show survival rates compatible with the average for the entire collection (45.11\%). 


\begin{tabular}{lllll}
\hline & $\begin{array}{l}\text { Target language } \\
\text { Latin }\end{array}$ & $\begin{array}{l}\text { Target language } \\
\text { Dutch }\end{array}$ & $\begin{array}{l}\text { Target language } \\
\text { French }\end{array}$ & Total \\
\hline $\mathrm{P} 1$ & 1,859 & 3,541 & 748 & 6,008 \\
$\mathrm{P} 2$ & 845 & 805 & 224 & 1,816 \\
$\mathrm{P}($ found) in \% & 59.75 & 36.58 & 45.11 & 45.41 \\
$\mathrm{P}($ lost $)$ in $\%$ & 40.25 & 63.42 & 54.89 & 54.59 \\
$\mathrm{~N}($ found $)$ & 3,975 & 5,514 & 1,149 & 10,339 \\
$\mathrm{~N}($ lost $)$ & 2,678 & 9,560 & 1,398 & 12,428 \\
$\mathrm{~N}$ (total) & 6,653 & 15,074 & 2,547 & 22,767 \\
& & & & \\
\hline
\end{tabular}

Editions in Latin consist on average of 39.82 sheets per copy, works in Dutch of 12.04 sheets and French books of 17.94 sheets. The results for works in black letter (11.33 sheets per copy) and Dutch-language works (12.04 sheets) are consistent throughout the entire dataset. The crucial feature is language, because Dutch-language editions undergo a significant shift in their predominant choice of type in the course of the seventeenth century. Before the 166os, the majority of books in Dutch were set in black letter, but with time, the majority of those editions will appear in roman type. ${ }^{26}$

\section{Place of Publication}

This also explains the survival rates according to place of publication (table 8.7). For Antwerp, 2,187 editions in this dataset were published in Latin against 3,217 in Dutch (41.24\% respectively $58 \%$ of Antwerp production). The estimated survival rates for Louvain are much better $(64.03 \%)$. This is beyond any doubt related to the academic status of the city, which housed a university since 1425. The largest part of the city's output was in Latin (925 editions or $78.99 \%$ of the Louvain production), against 223 Dutch-language books, representing only $19.04 \%$ of the editions in this corpus. It is not clear how the distribution of Dutch-versus Latin-language books should be assessed for Ghent and Brussels.

26 Goran Proot, 'The evolving typographical identity of theatre programmes produced for the Flemish Jesuits in the seventeenth and eighteenth centuries', in William A. Kelly and 
TABLE 8.7 Place of publication

\begin{tabular}{llllll}
\hline & Antwerp & Ghent & Brussels & Louvain & Total \\
\hline P1 & 3,256 & 922 & 879 & 558 & 6,008 \\
P2 & 862 & 267 & 279 & 285 & 1,816 \\
P(found) in \% & 41.16 & 44.01 & 47.04 & 64.03 & 45.41 \\
P(lost) in \% & 58.84 & 55.99 & 52.96 & 35.97 & 54.59 \\
N(found) & 5,546 & 1,482 & 1,451 & 1,171 & 10,339 \\
-In Latin & 2,187 & 268 & 410 & 925 & \\
& $(42.24 \%)$ & $(18.08 \%)$ & $(28.26 \%)$ & $(78.99 \%)$ & \\
- In Dutch & 3,217 & 1,100 & 488 & 223 & \\
& $(58 \%)$ & $(74.22 \%)$ & $(33.63 \%)$ & $(19.04 \%)$ & \\
N(lost) & 7,930 & 1,885 & 1,633 & 658 & 12,428 \\
N(total) & 13,476 & 3,367 & 3,084 & 1,829 & 22,767 \\
& & & & & \\
\hline
\end{tabular}

\section{Subject Matter}

According to the model, works dealing with Christian Doctrine are preserved best in this sample, which should include six out of ten editions originally published. 'Christian Doctrine' is a very broad category, consisting of all works directly or indirectly related to religious issues, such as sermons, devotional books, religious treatises and lives of saints, but also literary works which are religiously motivated, such as moralising emblem books. The average sheet count is 22.79 sheets per copy - slightly over the overall average of all works in this survey. ${ }^{27}$

Giulia Trentacosti (eds.), The Book in the Low Countries (Edinburgh: Merchiston Publishing, 2015), pp. 11-53, here: pp. 32-33 (diagrams 9, 10 and 11). More details about this transition according to text genre and on the title page can be found in Goran Proot, 'De opmars van de romein. Het gebruik van romein en gotisch in Nederlandstalig drukwerk uit de zuidelijke Lage Landen, 1541-170o', Jaarboek voor Nederlandse boekgeschiedenis, 19 (2012), pp. 65-85. For a comparative survey for Dutch-language editions published in the Dutch Republic and the Southern Netherlands, see Steven van Impe and Jan Bos, 'Romein en gotisch in zeventiende-eeuws drukwerk. Een voorbeeldonderzoek voor het gebruik van de STCN en STCV', De zeventiende eeuw, 22 (2006), pp. 283-297.

27 The distribution of sheets required to produce one copy of an edition recorded in the sample for Christiane Doctrine is the following: $\leq 1$ sheet per copy: $285 ; 1 \leq 2$ sheets per 
The category of state publications - regulations, ordinances and official declarations, issued by official bodies, such as the Antwerp Gheboden ende wtgheroepen - shows the most important loss: almost eight in ten editions have not yet been recorded $(77.18 \%$ of the estimated total output; see table 8.8 ). The average sheet count for this category is 3.84 sheets per copy, and $60.33 \%$ of all recorded editions were produced using only one sheet or under, ${ }^{28}$ which is the category of works most susceptible to loss $(86.94 \%$, see table 8.3). The number of quartos in this category is also considerable: 1,484 in 1,853 recorded editions $(80.08 \%)$. The loss rate of quartos, irrespective of their size, is estimated at $66.03 \%$ (table 8.4).

\section{Sammelbände}

In contrast to most other bibliographies, the STCV systematically records when a copy added to the database was found in a Sammelband, a volume consisting of two or more codicological entities, be it in print or in manuscript. No difference is made between contemporary or more recent volumes. The following

TABLE 8.8 Subject matter

\begin{tabular}{lllllll}
\hline & $\begin{array}{l}\text { Christian } \\
\text { doctrine }\end{array}$ & $\begin{array}{l}\text { History (all } \\
\text { combined) }\end{array}$ & $\begin{array}{l}\text { Language } \\
\text { and literature }\end{array}$ & $\begin{array}{l}\text { State } \\
\text { publications }\end{array}$ & $\begin{array}{l}\text { Topical } \\
\text { publications }\end{array}$ & Total \\
\hline P1 & 1,837 & 1,059 & 583 & 1,485 & 1,000 & 6,008 \\
P2 & 864 & 292 & 182 & 192 & 277 & 1,816 \\
P(found) in \% & 61 & 42.44 & 46.49 & 22.82 & 42.58 & 45.41 \\
P(lost) in \% & 39 & 57.56 & 53.51 & 77.18 & 57.42 & 54.59 \\
N(found) & 3,819 & 1,860 & 1,080 & 1,853 & 1,596 & 10,339 \\
N(lost) & 2,441 & 2,523 & 1,243 & 6,267 & 2,152 & 12,428 \\
N(total) & 6,260 & 4,383 & 2,323 & 8,120 & 3,748 & 22,767 \\
& & & & & & \\
\hline
\end{tabular}

copy: $307 ; 2 \leq 4$ : 412; $4 \leq 8: 578 ; 8 \leq 16: 860 ; 16 \leq 32: 789 ; 32 \leq 64: 321 ; 64 \leq 128: 138 ; 128 \leq 256$ : 110 ; and $256 \leq 512$ : 19 .

28 The distribution of sheets required to produce one copy of an edition recorded in the sample for State Publications is the following: $\leq 1$ sheet per copy: 1,118; $1 \leq 2$ sheets per copy: 295; $2 \leq 4$ : 225; $4 \leq 8$ : $85 ; 8 \leq 16$ : 59; $16 \leq 32: 38 ; 32 \leq 64: 25 ; 64 \leq 128: 3 ; 128 \leq 256$ : 4 ; and $256 \leq 512: 1$. 
numbers thus reflect the situation as assessed by the bibliographers entering copies since 1 February 2000. The analysis of this feature is revealing. More than $40 \%$ of all copies in the retrospective bibliography are part of a Sammelband (15,916 in 39,084 copies as of 5 May 2015). In the corpus under consideration, this number is slightly lower: $37.39 \%$ (Table 8.9 ).

The importance of Sammelbände becomes even more obvious when related to the number of sheets required to produce a copy of an edition. Almost three in four copies which are made out of one sheet or less are found in a Sammelband, and for works twice or four times this size, that is the case for more than half the number of copies. For editions counting 4 up to 8 sheets, $47.49 \%$ of all copies are to be found in a binding with other texts. As demonstrated by Fig. 8.9, the fact that printed editions are bound together is of great importance. The horizontal line marks the average number of copies in Sammelbände in this corpus, at $37 \cdot 39 \%$.

It is illuminating to compare these findings with the estimated survival rates for each category of editions grouped according to their volume in sheets. Supposedly only about $13 \%$ of all editions consisting of one sheet or fewer are recorded in the corpus. If only independent copies had been entered, this number would drop to about $3.5 \%$ ! Similarly, the survival rates for works of 1 to

80
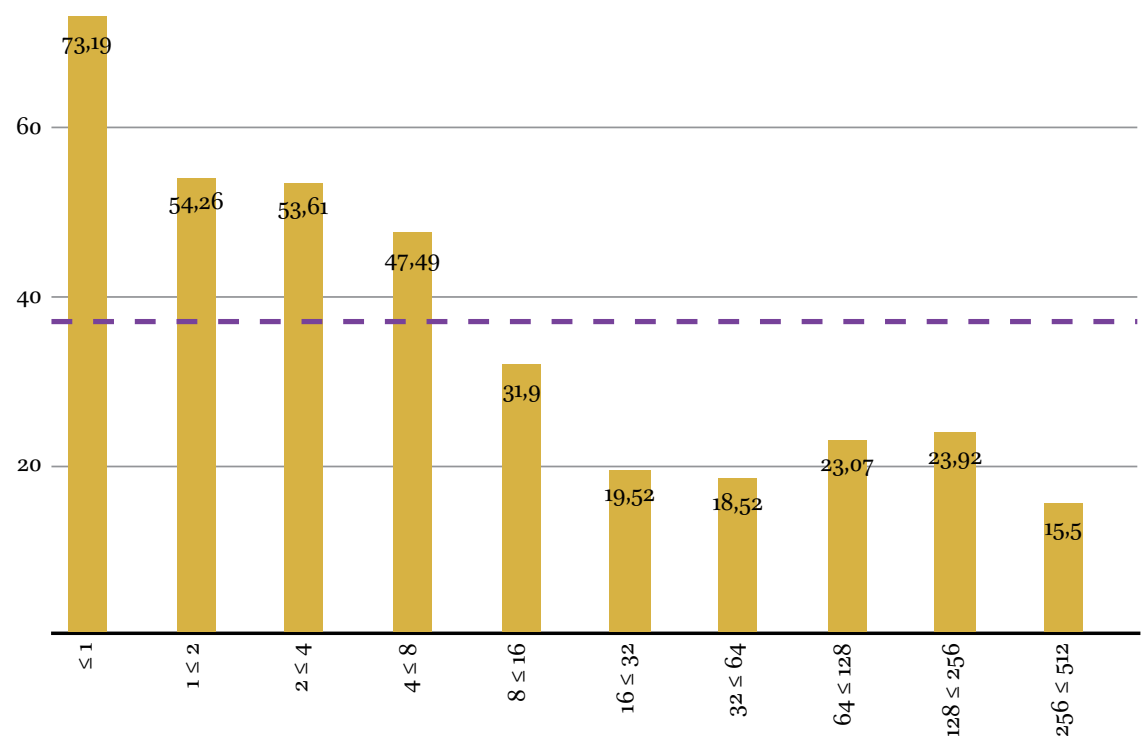

FIGURE 8.9 The percentage of copies found in a Sammelband, per category of editions with a specific number of sheets per copy 
TABLE 8.9 Copies as part of a Sammelband

\begin{tabular}{|c|c|c|c|c|c|c|c|c|c|c|c|}
\hline & $\leq \mathbf{1}$ & $1 \leq 2$ & $2 \leq 4$ & $4 \leq 8$ & $8 \leq 16$ & $16 \leq 3^{2}$ & $3^{2} \leq 64$ & $64 \leq 128$ & $128 \leq 256$ & $25^{6} \leq 5^{12}$ & Total \\
\hline Copies & 2,536 & 1,454 & 2,035 & 2,784 & 3,781 & 3,965 & 2,506 & 1,231 & 945 & 329 & 21,566 \\
\hline Copies in a & 1,856 & 789 & 1,091 & 1,322 & 1,206 & 774 & 464 & 284 & 226 & $5^{1}$ & 8,063 \\
\hline \multicolumn{12}{|l|}{ Sammelband } \\
\hline Percentage & 73.19 & 54.26 & 53.61 & 47.49 & 31.9 & $19 \cdot 5^{2}$ & $18.5^{2}$ & 23.07 & 23.92 & $15 \cdot 5$ & $37 \cdot 39$ \\
\hline
\end{tabular}

8 sheets per edition would more or less be halved, too. The impact of Sammelbände is of a considerable importance especially for relatively short printed texts.

\section{Printers' Profiles}

Amongst the above described survival and loss factors, the number of sheets required for the production of a copy is the one with the greatest impact on the presence of works in institutional collections. The pattern described in table 8.3 and illustrated by fig. 8.7 is instrumental in the assessment of a printer's output in the Southern Netherlands during the seventeenth century and to interpret his or her position in their region and time frame.

Table 8.10 describes the output of six printers, who can be classified in two groups. The first group consists of four printers who focus on small jobs, whereas the printers in the second group (Aertssens and Verdussen) are more involved in the printing and publishing of voluminous works. The six printers discussed here are not taken randomly, but they serve as representative examples for the most important printer's profiles in the analysed corpus.

The corpus contains 398 editions printed and/or published by the Antwerp printer Abraham Verhoeven. ${ }^{29}$ Although he is in terms of editions one of the most productive printers in the city, the total recorded number of sheets is negligible. The bulk of this activity consists of topical, one sheet or half sheet publications, in general news pamphlets commenting on recent events. The

29 For secondary literature about Abraham Verhoeven, see Koen de Vlieger-de Wilde (ed.), Directory of seventeenth-century printers, publishers and booksellers in Flanders (Antwerp, Vereniging van Antwerpse Bibliofielen, 2004), pp. 73-74 (no. 145). 
TABLE 8.10 Recorded output of six printers according to sheets per copy

$\leq 1 \quad 1 \leq 2 \quad 2 \leq 4 \quad 4 \leq 8 \quad 8 \leq 16 \quad 16 \leq 3^{2} \quad 3^{2} \leq 64 \quad 64 \leq 128 \quad 128 \leq 256 \quad 256 \leq 512$ Total

\begin{tabular}{llllllllllll}
\hline A. Verhoeven & 372 & 17 & 8 & 0 & 0 & 1 & 0 & 0 & 0 & 0 & 398 \\
Editions in \% & 93.47 & 4.27 & 2.01 & 0 & 0 & 0.25 & 0 & 0 & 0 & 0 & 100 \\
H. Saetreuver & 34 & 26 & 15 & 9 & 4 & 1 & 0 & 0 & 0 & 0 & 89 \\
Editions in \% & 38.2 & 29.21 & 16.85 & 10.11 & 4.49 & 1.12 & 0 & 0 & 0 & 0 & 100 \\
H. Anthoon & 27 & 23 & 14 & 11 & 6 & 5 & 4 & 1 & 1 & 0 & 92 \\
Editions in \% & 29.35 & 25 & 15.22 & 11.96 & 6.52 & 5.43 & 4.35 & 1.09 & 1.09 & 0 & 100 \\
B. Manilius & 62 & 69 & 45 & 23 & 10 & 6 & 2 & 1 & 0 & 0 & 218 \\
Editions in \% & 28.44 & 31.65 & 20.64 & 10.55 & 4.59 & 2.75 & 0.92 & 0.46 & 0 & 0 & 100 \\
H. Aertssens & 4 & 4 & 10 & 24 & 45 & 72 & 27 & 7 & 6 & 2 & 201 \\
Editions in \% & 1.99 & 1.99 & 4.98 & 11.94 & 22.39 & 35.82 & 13.43 & 3.48 & 2.99 & 1 & 100 \\
H. Verdussen I & 20 & 9 & 27 & 58 & 63 & 57 & 40 & 14 & 12 & 3 & 303 \\
Editions in \% & 6.6 & 2.97 & 8.91 & 19.14 & 20.79 & 18.81 & 13.2 & 4.62 & 3.96 & 0.99 & 100
\end{tabular}

sum of sheets required to print one copy of each of his publications amounts to 443.25 sheets. Divided over about 21 years of activity $(1609-1630)$, this is a mere 21.10 sheets per year. ${ }^{30}$ Expressed in formes which needed to be composed, this equals barely 43 formes, inner and outer formes combined, per year.

The production of the Ghent printer Hendrick Saetreuver, who succeeded Baudewyn Manilius in 1684 and remained active until 1700, is marked by a pattern that is in some ways similar to that of Abraham Verhoeven, but it also shows more diversification in term of sheets per copy. ${ }^{31}$ In quantitative terms, one-sheet publications constitute the largest category, followed by other small works, consisting of up to two or four sheets per copy. Those three categories represent almost $85 \%$ of his production. The corpus records only a few works of a considerable volume, the most voluminous being the Imago veri advocati,

30 The sTCV records activity from 1609 onwards until 1630, see, for instance, sTCV 6622985 (1609) or STCV 12918860 (1630).

31 For secondary literature about Hendrick Saetreuver, see de Vlieger-de Wilde, Directory of seventeenth-century printers, publishers and booksellers in Flanders, p. 121 (no. 258); for Manilius: p. 117 (no. 250). 
a law book published in 1687 as a quarto consisting of 111 leaves. ${ }^{32}$ His output in terms of sheets totals 253.75 sheets (507.5 formes), representing almost 32 formes per year of activity, which is even less than what is known for Verhoeven.

As illustrated by fig. 8.10, the production in the corpus by the Brussels printer Huybrecht Anthoon I (active 1615-1630) ${ }^{33}$ and the Ghent printer Baudewijn Manilius (active 1649-1684) follows the same pattern. ${ }^{34}$ Their output profile is

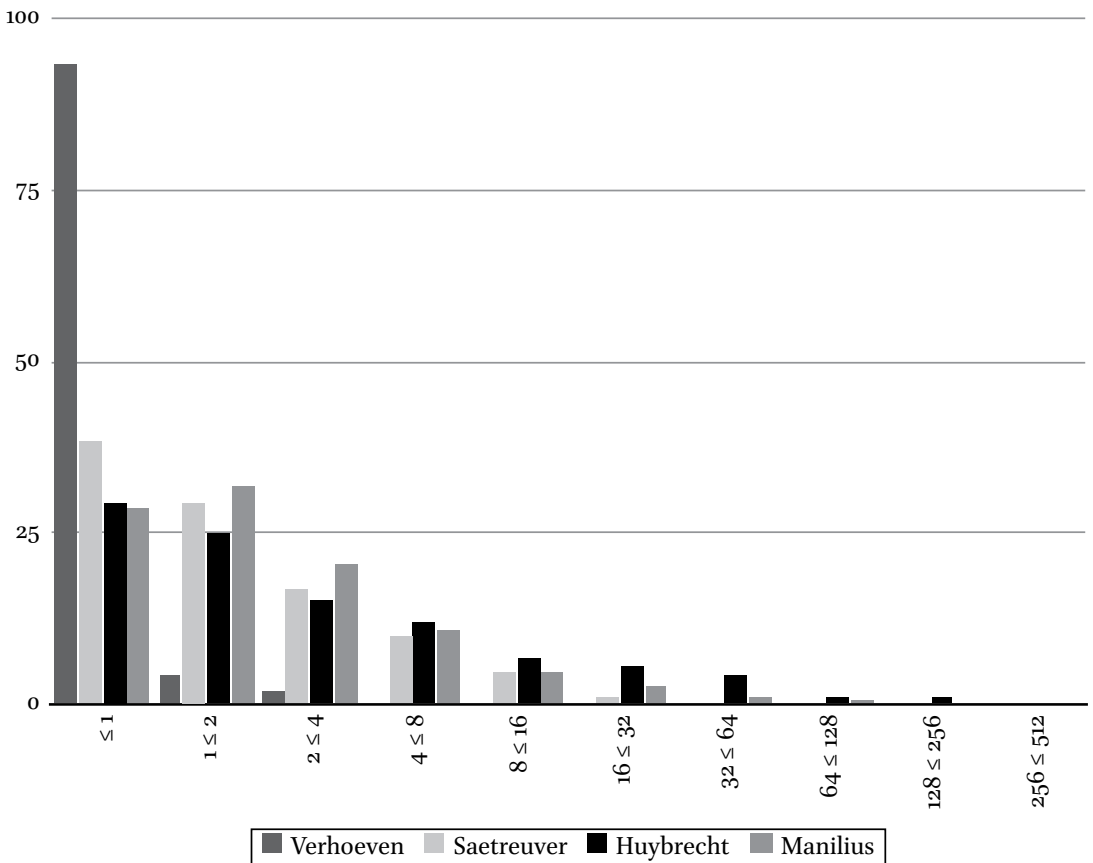

FIGURE 8.10 Recorded production of Verhoeven, Saetreuver, Huybrecht and Manilius according to the number of sheets per copy of their editions, in relative numbers

32 STCV 6596783 . The work, which has both an engraved and a typographical title page, is recorded in eight copies.

33 For secondary literature about Huybecht Anthoon I, see de Vlieger-de Wilde (ed.), Directory of seventeenth-century printers, publishers and booksellers, p. 90 (no. 184).

34 Huybrecht Anthoon I produced 760.90 sheets for 92 editions in 15 years (or almost 102 formes per year), Baudewijn Manilius 824.75 sheets for 218 editions in 35 years (47.13 formes per year). 
characterised by a right skewed distribution. ${ }^{35}$ The largest part of their work consists of slim editions, in addition to a small amount of 'real books'. All four printers can be characterized as jobbing printers, who lived off small jobs for local audiences. This production was vital to their business, as is demonstrated by the fact that Manilius went to the trouble of drawing up a framework agreement for the production of theatre programmes for the Ghent Jesuits. ${ }^{36}$ Within this jobbing market, there is even room for further specialisation for pamphlet printers such as Verhoeven.

The second group consists of printers who produce books of all lengths, with a preference for works of 8 to 32 sheets per copy. As fig. 8.11 indicates, their output is nicely balanced and comes close to a standard normal distribution

40

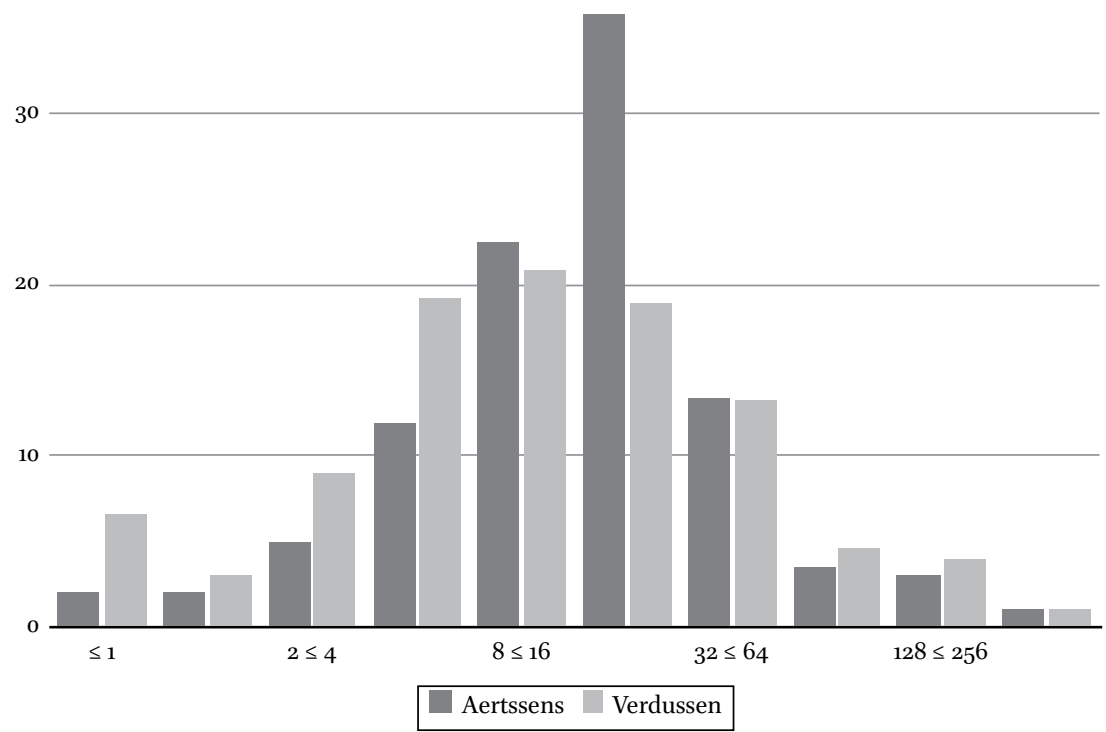

FIGURE 8.11 Recorded production of Aertssens and Verdussen according to the number of sheets per copy of their editions, in relative numbers

35 For an introduction to skewness of distributions, see, for instance, Bruno Blondé et al., Trend en toeval. Inleiding tot de kwantitatieve methoden voor historici (Louvain: Leuven UP, 2012), pp. 75-76.

36 Proot, 'The importance of jobbing printing'. 
(Gauss clock). Both Hendrick Aertssens I (active 1613-1656) and Hieronymus Verdussen I (active 1589-1635) were very prolific businessmen. ${ }^{37}$ Of the former, the corpus contains 201 books for a total of almost 5,955 sheets, of the latter it contains 303 titles between 1601 and 1633 for a total of almost 9,167 sheets - the sixteenth-century production by Hieronymus Verdussen I is not included in this analysis. ${ }^{38}$ The average length of Aertssens' books is 29.63 sheets per copy, that of Verdussen 30.25 sheets. Recalculated as formes per year, Aertssens had his compositors produce 277 formes per year, and for Verdussen this is $5^{24}$ formes per year.

80

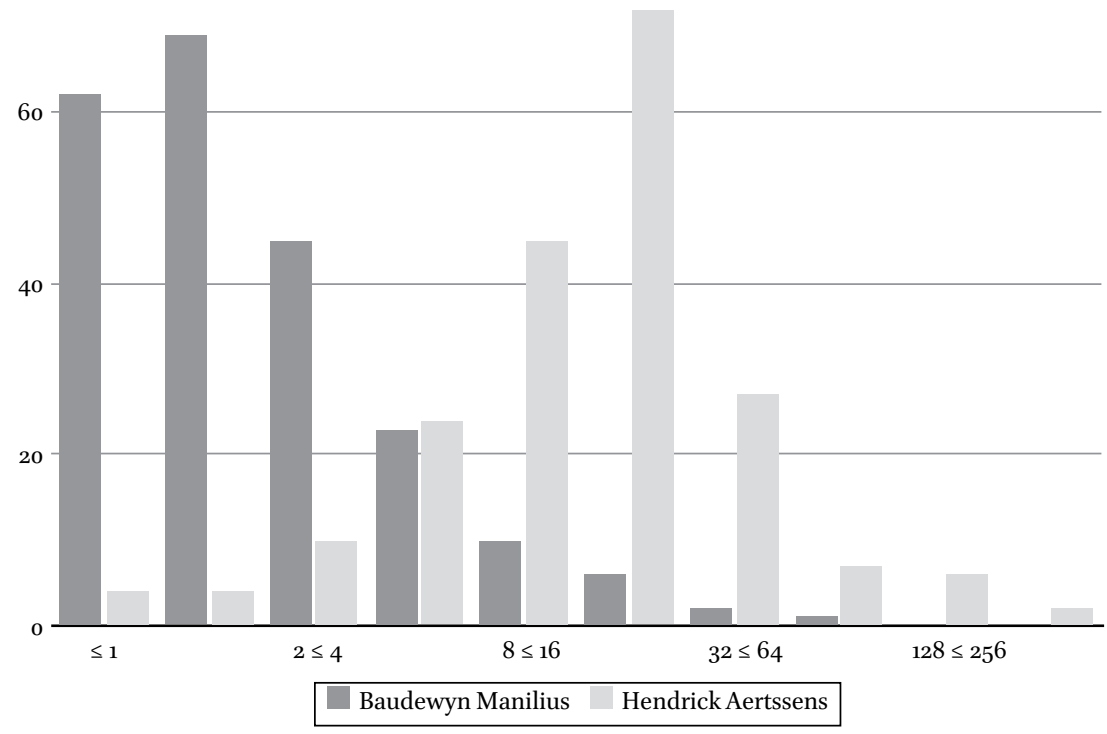

FIGURE 8.12 The recorded output for Baudewyn Manilius and Hendrik Aertssens I

37 For secondary literature about Hendrick Aertssens I, see de Vlieger-de Wilde (ed.), Directory of seventeenth-century printers, publishers and booksellers, p. 23 (no. 1); for Hieronymus Verdussen I, p. 69 (no. 137). Stijn van Rossem provides an analysis of the publishing activities of the first three generations Verdussen in his prize-winning study Het gevecht met de boeken. De uitgeversstrategieën van de familie Verdussen (Antwerpen, 1589-1689) (Antwerp: Universiteit Antwerpen, 2014).

38 Stijn van Rossem records 396 editions for Hieronymus Verdussen I, 362 of which were published between 1601 and 1635 . At present, not all of them have been entered in STCV. 


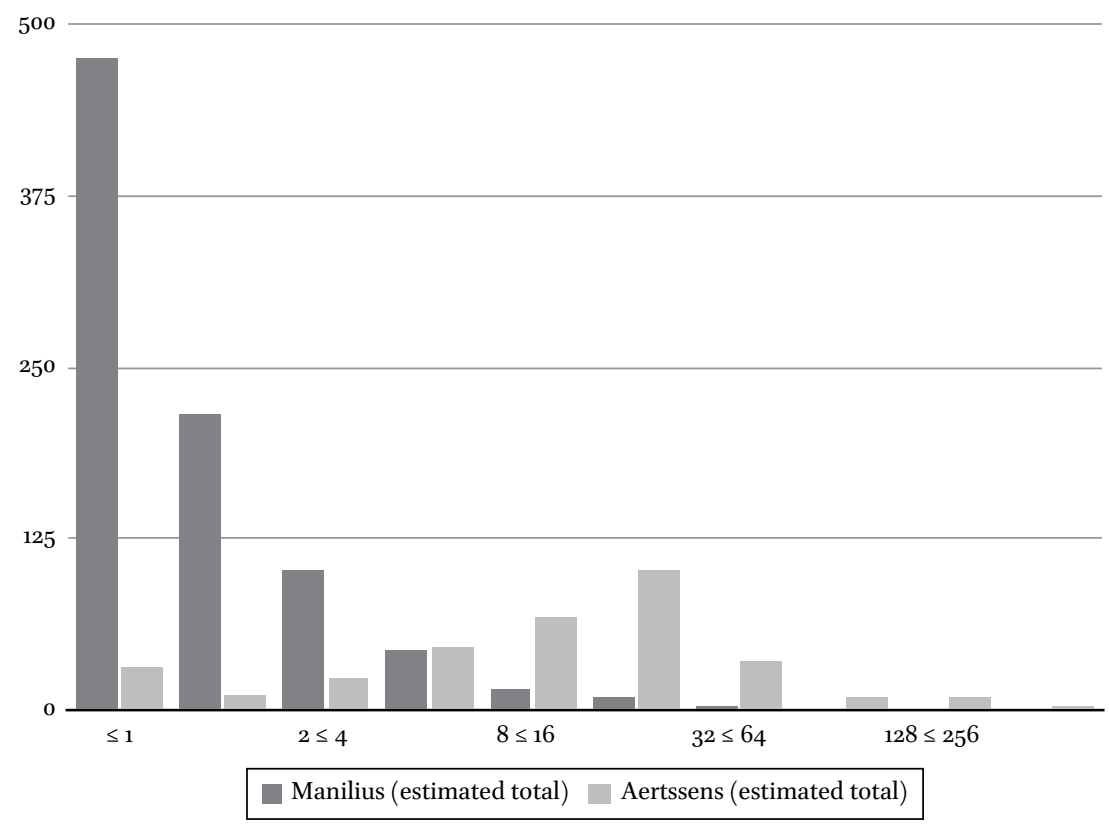

FIGURE 8.13 Potential total production by Baudewyn Manilius and Hendrik Aertssens I (very rough estimates, based on table 8.3 )

Almost all seventeenth-century printers/publishers in the Southern Netherlands show a production profile similar to that of one or other of these groups. The comparison of both groups in terms of sheets per edition shows how printers developed specific specialisations. The contrasts between them were even more marked than those demonstrated by figs. 8.10 and 8.11, because one should also factor in the loss rates for each of the categories of publications. The difference between what is recorded and what that output may represent hypothetically, may be indicated by figs. 8.12 and $8.13 .{ }^{39}$ Since his production concentrates on single sheet jobs, the lion's share of a jobbing printer's output remains in most cases unrecorded. Printers such as Abraham Verhoeven, Baudewijn Manilius or Hendrick Saetreuver could only survive by the grace of large quantities of small jobs, many more than will ever be documented by surviving copies. This is why some of them went to the trouble of writing up

39 The numbers on which the calculated estimates of fig. 8.13 are based are too weak $(<1,000)$ to provide realistic numbers; therefore this graph should not be taken literally, but only serves as an illustration. 
framework agreements for jobs as small as one sheet editions, such as theatre programmes. ${ }^{40}$

\section{Conclusion}

This chapter focused on the estimation of the actual print output in the Southern Netherlands in the seventeenth century. For methodological reasons, this survey was based on a dataset generated by the retrospective bibliography for the region of present day Flanders, the Short Title Catalogue Flanders (STCV). Only records of single volume editions, with an established format and collation formula, and a certain Flemish origin, were included in the analysis. For the estimation of editions recorded ('found') and not (yet) recorded ('lost') in the online bibliography, I used a scientific, stochastic calculation model for multi-copy documents developed in 2007 by Leo Egghe and myself. When used on coherent, controlled datasets of sufficient size in which editions are described based on actual copies, it is possible to estimate how large the fraction is of recorded editions in comparison to the fraction of editions with similar characteristics that are not present in the dataset.

The analysis of the entire dataset reveals that the STCV currently has an estimated coverage of about $45 \%$. In other words, this means that about $55 \%$ of the editions, which are commonly collected by institutional libraries and archives represented in this specific online bibliography, are not recorded. Against 10,339 different known editions, there are about 12,428 unknown editions. Analysis of subsets show that some works have better survival rates than others. Two factors are of paramount importance: the number of sheets of paper required to produce one copy of a specific edition, and Sammelbände.

40 See Proot, 'The importance of jobbing printing'. For the Dutch Republic, a rare exception is the Utrecht university printer François Halma (1653-1722), who printed seven hundred doctoral theses in the period $1685^{-1698}$, or about one thesis per week for 13 years in a row. As Kuniko Forrer points out in her article, these ephemera had "no commercial value and never entered into the normal distribution channels." Cf. Kuniko Forrer, 'Dutch academic theses and printed matter', Kelly and Trentacosti (eds.), The book in the Low Countries, pp. 55-79, here: p. 57. The material survives as Halma had a contract with the university, as a result of which a copy of each thesis he produced was collected by the university - in Sammelbände. This collection is preserved at Utrecht University Library. 
More sheets result in significantly higher chances of being recorded in STCV; survival rates go up each time the amount of paper is doubled. ${ }^{41}$ This fundamental insight into the correlation between sheets per copy and survival is important to re-assess the recorded output of printers and their relative position within the trade, even if large parts of their work have not left any bibliographical traces.

The bibliographic format of the book also has an important impact on survival. Surprisingly, seventeenth-century octavo books have better survival rates than books in other formats. Duodecimos are second, followed by folios, even though folio editions count, on average, more sheets per edition. The other 'big format', quarto, turns out to be the bibliographic format most prone to loss. This can be explained by the text genres which are usually produced as quartos: ephemeral or topical publications, in addition to state publications. In addition to bibliographic format, the presence of an engraved title page raises survival rates considerably. Furthermore, works set in roman type have better chances of preservation in institutional collections than works set in black letter, and the same goes for books in Latin, which show significantly better survival rates than those in the vernacular. Even the place of publication has an impact, as editions produced in Louvain, the academic centre of the country, are preserved in larger quantities than books produced elsewhere.

Almost $37 \%$ of seventeenth-century printed output in Flanders received the subject term 'Christian Doctrine', a very broad category of works related to religious subjects. As a whole, this category is preserved best (61\% survival) compared to other large categories, such as, for instance, History or Language and Literature.

Another important observation is the fact that, for the Southern Netherlands, small publications, i.e., those for which a couple of sheets of paper suffice to produce a copy, owe their survival largely to the Sammelband. Those made-up volumes are omnipresent in the collections contributing to the STCV: almost two editions in five are found in Sammelbände, a fact that therefore requires much more research. It is my feeling that, compared to the Continent, works are disbound much more often in the English book world, which would prompt the question whether or not this impacts survival rates, and exactly how.

Intellectual output - Latin, in roman type, produced in an academic centre and works broadly related with religion, have better chances of ending up in

41 An important nuance to Gilmont's intuition: "Il semble cependant que la masse d'un ouvrage (format et épaisseur) soit favorable à sa conservation”, Gilmont, 'Livre, bibliographie et statistiques', p. 806 . 
institutional collections. Those categories do not only reflect some of the main interests of people in the seventeenth century - an era marked by the CounterReformation in which mainly Jesuits held the pen - but they also inform us about the views of those people acting as gatekeepers of collections in that and the following centuries, what they esteemed relevant enough, valuable enough and important enough to hand down to future generations. Put this way, the books preserved in institutional collections, which are in turn described in the STCV, are eventually based in social and cultural values which marked our past and which continue to do so today. This survey therefore not only sheds light on features related to survival of individual items, but even more so on the nature of institutional collections, how they were built, and what they hold or intend to hold - and what not. The social and cultural motivation for those choices invites further research - a history of the de-selection of institutional collections still remains to be written.

In part, the work presented here offers an answer to some fundamental questions put forward by Gilmont, McKenzie and many others. The former lamented "Au fond, on ignore encore largement ce qui faisait le prix d'un livre, pourquoi on le conservait et pourquoi on le laissait se détériorer." ${ }^{22}$ McKenzie formulated it as follows:

There is another problem facing anyone who would study printing and even publishing firms as economic units: establishing precisely who printed and published what. (For wholesalers and retailers there is the further problem of determining their trade in imports and in secondhand books.) The short-title catalogues of books printed in England, Scotland, and Ireland and of English books printed abroad from about 1475 to 1800 supply the only comprehensive evidence we have, but those record only the texts still extant. It may not be much of an exaggeration to say that at least a third of the different items printed in the midseventeenth century have since been lost. The fact that books survive better than ephemera also skews the record: in the few cases where printers' archives survive, jobbing work (most of it otherwise unknown) bulks large. Usually it is quite incalculable. ${ }^{43}$

42 Gilmont, 'Livre, bibliographie et statistiques', p. 811.

43 D.F. McKenzie, 'The economies of print, 1550-1750: Scales of production and conditions of constraint', in Cavaciocchi (ed.), Produzione e commercio della carta e del libro, pp. 389-425, here p. 394 . 
It must be admitted that an important part of printed output will probably always escape finer estimations - that is the real 'dark matter', which was, from the outset, not considered important enough to be preserved. But what past generations did value survived at least in part, and sometimes in large enough quantities that it is possible to form a reasonable idea. ${ }^{44}$

44 I would like to thank Allan B. Farmer, who was so kind to share with me a draft of an article about the same problem of estimating lost editions. In that contribution, Farmer analyses edition statements of second and following editions of English books published before 1641 and their presence in STC. 